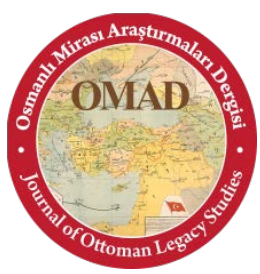

Osmanlı Mirası Araştırmaları Dergisi (OMAD), Cilt 4, Sayı 10, Kasım 2017, ss. 1-26.

Journal of Ottoman Legacy Studies (JOLS), Volume 4, Issue 10, November 2017, pp. 1-26.

ISSN 2148-5704

DOI Number: 10.17822/omad.2017.69

Geliş Tarihi/Received: 31.10.2017～Kabul Tarihi/Accepted: 13.11.2017

\title{
TRABZON RUM METROPOLITLERİ HAKKINDA BAZI GÖZLEMLER (1610-1670)
}

\author{
Some Observations about the Greek Metropolitans in Trabzon (1610-1670)
}

\section{Turan AÇIK*}

Özet: Osmanlı İmparatorluğu şehirlerinin kozmopolit karakterinin en önemli figürlerinden olan metropolitler, devletin Hıristiyan reaya ile olan ilişkilerindeki bağlantı noktalarından biri idi. Bilhassa Fatih dönemi ile birlikte Osmanlı teşkilat yapısı ile uyumlu hâle getirilen metropolitlik kurumunun devlet ve Hıristiyan tebaa arasındaki konumunu ise büyük nispette vergiler belirlemekteydi. İşte bu bağlantı noktaları eksenli ilişki 17. yüzyıldaki "kriz" ortamından nasıl etkilenmişti? Şer'iye sicilleri, mühimme defterleri ve piskopos mukataası kalemi defterlerinden elde edilen veriler nispetinde ortaya çıkan netice, Trabzon özelinde metropolitlik kurumunun gerek ehl-i örfün müdahalesi, gerekse metropolitlerin kendi haksız tasarrufları ile kendi "krizini” yaşadığı istikametinde idi. Bu "krizin" 18. ve 19. yüzyılda İmparatorluk ve gayrimüslim reayası arasındaki ilişkiyi nasıl etkilediğini ortaya çıkarmak için ise daha çok araştırmaya ihtiyaç olduğu açıktır.

Anahtar Kelimeler: Osmanlı İmparatorluğu, 17. yüzyıl, Trabzon, Metropolit

Abstract: Metropolitans, one of the most important figures of the cosmopolitan character of the Ottoman cities, were one of the connection points of the state with the Christian subjects. The position of the metropolitan institution, which was brought in line with the Ottoman organizational structure precisely during the reign of Mehmet II, between the state and the Christian subjects was determined mostly by the taxes. How have these connection points-centered relations been influenced by the "crisis" environment of the 17th century? The result that arises in relation to the data obtained from sharia court records, mühimme registers and piskopos mukataası kalemi registers was that the metropolitan institution in Trabzon had experienced their "crisis" either with the unjust dispositions of the metropolitans themselves or with the interventation of "ehl-i örf". It is clear that more research is needed to determine how this "crisis" affected the relationship between the goverment and the non-Muslim subjecst in the 18th and 19th centuries.

Key Words: Ottoman Empire, $17^{\text {th }}$ century, Trabzon, Metropolitan

\section{Giriş}

Tarih boyunca devletleri polis, kozmopolis (nizâm-1 âlem) ideali ile müşahhas imparatorluklar ve modern (ulus) devletler olmak üzere üçe ayırmak mümkündür. Osmanlı Beyliği de henüz kurulma aşamasında iken bulunduğu coğrafya itibarıyla çeşitli dinî ve etnik gruplarla ortak bir zemini paylaşmış; bilahare süratle icra edilen fetihlerle birlikte Fatih Sultan Mehmed dönemine kadar olan süreçte dinamik ve fetihçi bir imparatorluk nüvesi hâline gelerek fethettiği eski komşularını yeni tebaaları yapmıştır. ${ }^{3}$ Fatih dönemi ve sonrasında ise yine fütuhatçı ve teşkilatlanmış bir bürokratik imparatorluk hâline gelerek kozmopolis idealli imparatorlukların en başarılı örneklerinden birini inşa etmiştir. İşbu imparatorluğun kozmopolis ideali ve buna göre icra edilen bir teşkilat, kozmopolit şehirlerden (mahrûse/mahmiyye/medine) müteşekkil, eski dünyanın büyük kısmındaki imparatorluk geleneklerini tevarüs eden bir ülkeye (Memâlik-i Mahrûse-i Şahâne) hayat vermiştir.

\footnotetext{
* (Yrd. Doç. Dr.), Aksaray Üniversitesi, Fen-Edebiyat Fakültesi, Tarih Bölümü, Aksaray/Türkiye, e-mail: turanacik@gmail.com, ORCID: orcid.org/0000-0003-4682-6265

${ }^{1}$ Feridun M. Emecen, Osmanlı Klasik Çağında Hanedan Devlet ve Toplum, Timaş Yayınları, İstanbul 2011, s. 286.
} 
Hanedandan tebaasına, bürokrasisinden şehirlerine kadar kozmopolit bir hüviyeti haiz imparatorluk, Müslim veya gayrimüslim bütün tebaanın korunmasını (mahrûse içerisinde) ve toplumsal yapıdaki dengenin muhafazasını (adalet) ana politik eksen olarak belirlemiş; bu siyasal gündem ise devlet teşkilatını gayrimüslim unsurların idaresini de kapsayacak biçimde şekillendirmiştir. Bütün bu yapı ise Feridun Emecen'in belirttiği üzere "keyfî bir davranış1 çağrıştıran hoşgörü/tolerans kavramından öte, dayanağını hukukî kaidelerden" almıştır. ${ }^{2}$ İnalcık da devletin dinî cemaatlerle olan ilişkilerini düzenleyen aslî unsurun fikıh olduğunu belirtmektedir. ${ }^{3}$ Zira Osmanlı ülkesinin (Memâlik-i Mahrûse-i Şahâne) fikıhtaki karşılığı da Darü'l-İslam'dır. ${ }^{4}$

Zimmet hukuku denilen ve fikhın ehl-i kitâb gayrimüslim unsurların Müslüman bir "devlet" içerisindeki yaşam biçimini organize ettiği alt birimi, bu hukukî kaidelerin kaynağını teşkil ediyordu. Bunun yanında Osmanlı İmparatorluğu gibi, modern devletin nüvesini teşkil eden "medeniyetsel emperyal sistemlerde" ${ }^{5}$ şer`î hukukun yanında ve teoride onunla uyumlu olan örfî hukuk ${ }^{6}$ da gayrimüslimlerin Osmanlı ülkesi içerisindeki yaşamlarını organize etmekte önemli bir kaynaktı. 1516 tarihli Semendire Eflâkleri Kanunnâmesi'ndeki, "Şimdiden sonra despot kanunu demekle mâruf olan âyîn-i bâtıl dahi ref" olunup her hususta sancak beyi ve vilâyet kadıları muktezâ-yı şer'-i kavîm ve müsted'â-yı kanûn-1 kadîm üzere görüp fasl-1 husûmât-1 şer'iyye ve kat'-1 deâvî-i örfiyye eyleyeler" hükmü, şer' ve kanunun fonksiyonunu göstermek açısından önemlidir. ${ }^{7}$

Osmanlılar, bilindiği üzere ilk dönemlerinde gayrimüslimlerle İslâm hukuku ve örfün bir terkibi mahiyetindeki "istimâlet" politikası çerçevesinde bir ilişki tesis etmişlerdi. ${ }^{8} \mathrm{Bu}$ ilişki biçiminin kurumsal vechesini ve bu makalenin konusu açısından önemini gayrimüslim cemaatlerin ruhban zümresinin Osmanlılar tarafından tanınması ve devletle girdikleri ilişkide

\footnotetext{
2 Emecen, Osmanlı Klasik Çă̆ında Hanedan Devlet ve Toplum, s. 287. Bu hukukî kaideler dönemin şartları muvacehesinde Emecen'in belirttiği üzere "Müslüman tebaanın da pek dikkatini çekmemek şartıyla rahat bir yaşama ve hareket serbestisi tanıyordu.” Feridun M. Emecen, Tarihin İçinde Manisa, Manisa Belediyesi Kültür Yayınları, Manisa 2006, s. 117. Karen Barkey, "İslam'ın Yahudiler ve Hıristiyanlarla nasıl uğraşacağına dair bir alfabesi vardı" tespitini yapsa da son tahlilde Osmanlı İmparatorluğu’nun "çeşitliliği yönetmek için tercih ettiği çözüm”"ün "tolerans" olduğunu ifade etmektedir. Karen Barkey, Farklılıklar İmparatorluğu: Karşılaştırmalı Tarih Perspektifinden Osmanlılar, (çev. Ebru K1lıç), Versus Kitap, İstanbul 2011, s. 201, 204. Ortaylı ise "toleration" kavramının "hoşgörü" şeklinde tercüme edilmesine karşı çıkmakta, ayrıca 5000 yıldır "şehir medeniyeti” içerisinde yaşayan Osmanlı İmparatorluğu'nun ait olduğu havzanın birlikte yaşama tecrübesini kavramsallaştırmak için "tolerans" kelimesinin uygun olmadığını ifade etmektedir. Zira sosyopolitik anlamda burada yaşayan topluluklar uzun zamandan beri bu tecrübeye mâliktirler ve bir "sembiyosis" (ortak yaşama) içindedirler. Dolayısıyla ona göre imparatorluk da bu geleneğin devamcısıdır. İlber Ortaylı, Osmanlı Barışı, Ufuk Kitap Yayınları, İstanbul 2004, s. 48-55. Bilindiği üzere "Batı, ticaret kapitalizmi merhalesinde inanç farklılıklarıyla birlikte yaşamanın yolu olarak toleration kavramını bulmuştu. Ancak ticaretten sanayi kapitalizmine ve dinden ideolojiye doğru giderek artan modernleşme ve sekülerleşme sürecinde toleration kavramının da yetersiz kalması üzerine modus vivendi kavramı bulundu". Bedri Gencer, "Hikmet Çağından İdeoloji Çağına Müsâlemeden Muhâsamaya", Birlikte Yaşamak, (ed. Ahmet Kavlak-Muhammet Enes Kala), Hece Yayınları, Ankara 2015, s. 104.

${ }^{3}$ Halil İnalc1k, "The Status of the Greek Orthodox Patriarch under the Ottomans", Turcica, vol. 21-23, (1991), s. 408.

${ }^{4}$ Ahmet Özel, Dâruli̇slâm Dârulharb: İslâm Hukukunda Ülke Kavramı, İz Yayıncılık, İstanbul 2014.

${ }^{5}$ Bedri Gencer, “Osmanlı'da Meşruiyet Tabakalaşmasının Oluşumu”, İstanbul Üniversitesi Siyasal Bilgiler Fakültesi Dergisi, S. 30, (2004), s. 76.

${ }^{6}$ Halil İnalcık, Osmanlı Imparatorluğu Klâsik Çă̆ (1300-1600), (çev. Ruşen Sezer), Yapı Kredi Yayınları, İstanbul 2004, s. 76-82.

${ }^{7}$ M. Macit Kenanoğlu, "Zimmî (Osmanlılar'da)", D.I.A., C. 44, İstanbul 2013, s. 438. Zimmîler hakkında yapılan çalışmalara dair bir literatür değerlendirmesi için ayrıca bkz. Aynı yazar, "İslam-Osmanlı Hukukunda Zimmîler", Türkiye Araştırmaları Literatür Dergisi, C. 3, S. 5, (2005), s. 553-574.

8 "Fethedilen yerlerin halkına iyi davranma, onları himaye etme, dış düşmanlara karşı can ve mal güvenliğini sağlama, dinî konularda serbestiyet verme, vergi hususunda kolaylık gösterme Osmanlı istimâletinin başlıca unsurlarıdır. Aslında Kur'an’da (et-Tevbe 9/60) 'müellefe-i kulûb' şeklinde ifade edilen istimâlet siyaseti Osmanlı fetihlerini kolaylaştıran önemli bir ilke olarak benimsenmiștir." Mücteba İlgürel, "İstimâlet”, D.İ.A., C. 23, İstanbul 2001, s. 362. İstimâlet hakkında genel olarak bkz. Halil İnalcık, “Osmanlı Fetih Yöntemleri”, Söğüt'ten İstanbul'a: Osmanlı Devleti'nin Kuruluşu Üzerine Tartışmalar, (der. Oktay Özel-Mehmet Öz), İmge Yayınları, Ankara 2005, s. $443-472$.
} 
patrikliğin ve metropolitliğin muhatap alınması teşkil etmekteydi. Daha kuruluş yıllarından itibaren Osmanlılar, gayrimüslim unsurlara emannâmeler (Bursa ve İznik imtiyazları) vererek onların varlığını kabul etmiş ve tescil etmişlerdi. ${ }^{9}$ Yine daha İstanbul'un fethinden önce Osmanlı ülkesi içerisinde bulunan bölgelerdeki metropolitlerin tayinlerine dair belgeler bulunmaktadır. Elimizdeki ilk belgede, 1399 yılında I. Bayezid, fetihten önceki Antalya metropolitini yeniden tayin etmişti. Ayrıca I. Mehmed ve II. Murad dönemindeki Antalya metropolitlerine dair de belgeler bulunmaktadır. Yine Arnavutluk'ta da I. Mehmed ve halefleri zamanında metropolit tayin edildiği belgelendirilebilmektedir. ${ }^{10}$ İstanbul'un fethinden önce Osmanlı topraklarındaki söz konusu metropolitler ve cemaatlerinin ise Bizans İmparatorluğu'ndaki İstanbul Ortodoks Patrikliği ile ilişkileri kopuktu. Ortaylı'nın ifadesiyle "Osmanlı kontrolüne tabi oldukları muhakkaktı. Cemaatin adlî, malî, ruhanî ve eğitime ait işleri yerel rahip ve metropolitlerin sorumluluğuna bırakılmıştı."

Bilindiği üzere Fatih Sultan Mehmed İstanbul'u fethettikten hemen sonra Fener Rum Patrikhanesi'ni, 1461 yılında da Ermeni Patrikhanesi'ni teşkil ederek İmparatorluğun içerisinde yaşayan gayrimüslim Hıristiyan unsurların yaşam pratiklerini dinî, siyasî, idarî ve hukukî açıdan kurumsallaştırmıştı. ${ }^{12}$ Büyük ihtimalle Trabzon'un 1461 y1lındaki fethinden sonra da Trabzon Rum Tekfurluğu dönemindeki metropolit, Osmanlı İmparatorluğu tarafından yeniden tayin edilmişti. 1913 yılında Trabzon metropoliti olan Hrisanthos Flippidis'in vermiş olduğu listede 1422-1439-1472 yıllarında metropolitlik yapmış olan Dorotheos, fetihten sonra Osmanlı padişahı tarafindan tayin edilen ilk metropolitti. Bundan sonra bizim çalışma dönemimize gelene kadar sirasiyla Pangkratios (1472), II. Dorotheos (1472), Gennadios (1501), Gerasios (1506), II. Gennasios (1564), Maksimos (1570), II. Anthimos (1583), Theofanis (1591-1593), II. Gerasimos (1596-1610) ve İgnatios (1610-1620) metropolitlik makamında bulunmuşlardı. Bizim incelediğimiz dönemde atama beratlarını bulduğumuz ve haklarında bazı malumat edinebildiğimiz metropolitler ise yine Hrisantos'un verdiği sira ile Kenofon (1620-1628), Kirillos (1628-1638), III. Anthismos (1638/1639-1649), Lavrentios (1640/41-1659) ve Filotheos'tur (1659-1665). ${ }^{13}$

\section{Trabzon Metropolitlerinin Tayinleri ve Ödedikleri Pişkeşler}

17. yüzyılda, İmparatorluk bürokrasisinin kendi ifadesiyle devletin "hüsn-i himayeleri"14 altında olan gayrimüslim tebaaya verilen haklar, yine belgelerde ifade edildiği biçimiyle "şer" ve kanûn, kanûn-1 kadîm, kadîmden olugeldügi üzere, kadîmden olugelen âdet ve kanûn ve âyin-i bâtılaları üzere, mu'tâd-1 kadîm üzere" gibi kavramlar ekseninde değerlendirilmekte; dolayısıyla gayrimüslim tebaanın idaresi şeriat, gelenek ve kanun çerçevesinde icra edilmekteydi. Şeriat, gelenek ve kanun nokta-i nazarından "berât-1 hümâyun" ile tayin edilen patriklere ve metropolitlere verilen yetkilerin icrasına ise "şer" ve kanûna" mugayir olmamak koşulu ile "âyin-i bâtılaları, defter ve patrikin mektubu" kaynaklık etmekte idi.

\footnotetext{
${ }^{9}$ Kenanoğlu, "Zimmî (Osmanlılar'da)", s. 439. "Merkezî otoriteye” halel getirmeyecek şekilde verilen bu imtiyazlar, gayrimüslim unsurların Osmanlı öncesine ait kurumlarının devamını temin etmiştir. Tur-1 Sina Manastırı'ndaki ruhban taifesine verilen muafiyetlerin "burada yaşayan rahiplerin yakın çevreleri ve devlet ile ilişkileri bağlamında" ele alındığı bir yazı için bkz. Fatma Acun, "Osmanlı İmparatorluğu'nda Gayrimüslim Din Adamlarına Verilen İmtiyazlar: 16. Yüzyılda Tur-1 Sina Manastırı”, XIV. Türk Tarih Kongresi, 9-13 Eylül 2002, C. II, Kısım II, Türk Tarih Kurumu Yayınları, Ankara 2005, s. 1403-1411.

10 İnalc1k, "The Status of the Greek Orthodox Patriarch under the Ottomans", s. 415.

11 İlber Ortaylı, “Osmanlı İmparatorluğu’nda Millet”, Tanzimat'tan Cumhuriyet'e Türkiye Ansiklopedisi, C. 4, İletişim Yayınları, İstanbul 1985, s. 998.

12 Patrikliklerin teşkili hakkında tafsilat için bkz. Yavuz Ercan, Osmanlı Yönetiminde Gayrimüslimler, Turhan Kitabevi, Ankara 2001, s. 95-124. Patrik atamalarının siyasî, idarî ve hukukî boyutları hakkında bkz. Nuri Adıyeke, "Osmanlı Millet Sistemine Dair Tartışmalar ve Siyasal Bir Uzlaşma Modeli Olarak Osmanlı Millet Sistemi”, Yeni Türkiye, S. 60, (2014), s. 1-13.

${ }^{13}$ Hrisanthos Flippides, Eklisia Trapezontos, Estia Yayınevi, Atina 1933, s. 789'dan aktaran Aydın Özgeren, Millî Mücâdele Döneminde Trabzon Rum Metropolitliği'nin Faaliyetleri, Ankara Üniversitesi, Basılmamış Yüksek Lisans Tezi, Ankara 2006, s. 20-21.

${ }^{14}$ Trabzon Şer 'iye Sicilleri (T.Ş.S.), no: 1842, kayıt no: 70/1.
} 
Hrisanthos Flippidis'in ismini Kenofon olarak belirttiği metropolite dair 4 Zilkade 1028 (13 Ekim 1619) tarihli beratta, kâtibin ismini "İksanofon" olarak yazdığ rahip, daha önce "Trabzon ve tevâbii keferesinin" metropoliti olup "hüsn-i ihtiyârıyla fâriğ olan" İgnatyos (İgnatios) adlı rahip yerine İstanbul patriği Timotyos'un mektubu üzerine metropolit olarak tayin edilmişti. ${ }^{15}$ "Âdet-i pişkeşi” için 1028 Şevvali'nin 28. gününde (8 Ekim 1619) hazine-i âmireye nakit olarak 9.800 akçe teslim edince İksanofon'a (Kenofon) beratı verilmişti. ${ }^{16}$ Görüldüğü üzere metropolitlerin tayin ve azilleri hususunda patrikler "yetkili" idiler. Ölen, azledilen ya da feragat eden metropolitlerin yerine belirlenen bir kişiyi, patrik, mektupla Osmanlı merkez bürokrasisine bildiriyor, bu mektup üzerine de atama işlemi gerçekleştiriliyordu. Fakat kimi zaman reaya, patrik tarafından atanması için başvurulan metropoliti istemedikleri ve onun yerine kendi istedikleri bir metropolitin atanmasına dair merkeze şikâyette bulunabiliyorlar idi. Bunun yanında patrikleri tarafından görevden alınan metropolitler de padişaha müracaat ederek haksız bir şekilde metropolitlikten alındıklarını belirtip yerlerine iade edilmeyi talep edebiliyorlardı. Bu durum kadı tarafından araştırılıyor ve haklı olan tarafın hakkı iade ediliyordu. Dolayısıyla patrikler, metropolitleri tayin ve azilde diledikleri tasarrufta bulunamiyorlard. Hatta kimi zaman patriklere metropolit olarak kimin atanması gerektiği hususunda doğrudan müdahale edilebiliyordu. ${ }^{17}$

Atama beratında bilhassa vurgulanan husus, Kenofon'a beratının pişkeşi teslim ettikten sonra verilmiş olduğu idi. Bu durum yukarıda zikredilen kavramlar çerçevesinde şekillenen yetki tevdiinin özelde pişkeş ile müşahhas kılındığını göstermekteydi. Nitekim pişkeşin varlığ Macit Kenanoğlu'nu, İmparatorluğun, gayrimüslim tebaası ve bunların liderleri ile kurmuş olduğu münasebeti "ruhanî (dinî) iltizâm sistemi" kavramsallaştırması ekseninde izah etmeye yöneltmiştir. Beratlarda görülebileceği üzere pişkeş itibarıyla tayin edilen meblağ ödendikten sonra berat verilmekte; ödenmeden tayin işlemi gerçekleşmemekteydi. Bunun yanında "gayrımüslim ruhanî liderlerin kilise hukukundan ve hiyerarşik yapıdan kaynaklanan idarî ve malî yetkilerinin denetim dışı kalmaması, devletin otoritesinin kaybolmaması ve reayanın ezilmesinin önüne geçilebilmesi için, kilise adamlarının toplayacağı vergiler, iltizâm usulü ile kontrol altına alınmıştır." ${ }^{18}$ Pişkeş haricinde her yıl maktu olarak ödenen vergiler; iltizâm, ruhanîlik ve devlet otoritesi arasındaki bağı tesis etmişti. Ayrıca patrik veya metropolitin adlî hususlarda cemaati içerisindeki bazı anlaşmazlıkları bir arabulucu/hakem hüviyetinde çözebilmesinin yolu da pişkeşin ve her y1l ödenen maktu vergilerin ödenmesinden geçmekteydi. ${ }^{19}$ Dolayısıyla patrik ya da metropolitler, "millet sistemi" kavramı ekseninde otonom bir hüviyeti haiz olmaktan ziyade, padişah tarafindan atanan birer mültezimlerdi ve diğer mültezimlerden farkları ise sadece ruhanî bir sıfata sahip olmalarıydı. ${ }^{20}$ Fatih Sultan Mehmed dönemine tarihlenen bir metropolit kanunnamesinde de açıçca hazine-i âmireye bir rahibin belli bir miktar "pişkeş getürdügü̈ sebebden midrapolidliğin virdüm” denilerek pişkeş ve

\footnotetext{
${ }^{15}$ Charles Eliot'un verdiği bilgilere göre, 1620 yılında vezir-i âzam, on y1llık patrikliği boyunca 300 metropoliti "memuriyete" aldığı için Timotheus'tan 100.000 duka altını istemişti. Charles Eliot, Avrupa'daki Türkiye, C. 2, (çev. Adnan Sınar-Ş.Serdar Türet), Tercüman 1001 Temel Eser, ts, s. 60.

${ }^{16}$ T.Ş.S., 1821-4, 128/1. Dolayısıyla Metropolit Kenefon'un metropolitliğe atandığ 1 ve Hrisanthos'un 1620 olarak verdiği tarihi, 8 Ekim 1619 olarak kesinleştirmek mümkündür.

${ }^{17}$ M. Macit Kenanoğlu, Osmanlı Millet Sistemi: Mit ve Gerçek, Klasik Yayınları, İstanbul 2007, s. 167.

${ }^{18}$ M. Macit Kenanoğlu, “Osmanlı Devleti'nin Gayrimüslim Teb'anın İdaresinde Kullandığı Bir Yöntem Olarak 'Ruhanî İltizam’ Sistemi”, Dîvân İlmî Araştırmalar, S. 14, (2003/1), s. 76.

${ }^{19}$ Metropolitin arabulucu/hakem hüviyetinde dâhil olduğu bir dava kaydında; Kozala adlı zimmîye kadın eski damadı olan Ezam ile miras hususunda anlaşmazlık yaşamış, bunun üzerine Ezam kendine ait mülkün yarısını sulh yolu ile Kozala'ya vermişti; fakat söz konusu sulhu daha sonra inkâr etmişti. Bunun üzerine iki aded gayrimüslimin şehadetiyle sulh ikrar edilmiş, bunun dışında şahitler, "metropolid mahzarında zikrolunan evin nısfinı merkûme Kozala'ya virüb" diyerek verme işleminin metropolitin huzurunda gerçekleştiğini beyan etmişlerdi. Yine metropolid mahkemede "su'âl olunmuş" ve söz konusu evin verildiğini beyan etmişti. Bunun üzerine de Kozala davayı kazanmıştı. T.Ş.S., 1824, 48/7. Evâhir-i Receb 1042 (1-10 Şubat 1633).

${ }^{20}$ Kenanoğlu, “Osmanlı Devleti'nin Gayrimüslim Teb'anın İdaresinde Kullandığı Bir Yöntem Olarak 'Ruhanî İltizam’ Sistemi”, s. 77.
} 
tayin olma arasındaki sıkı irtibata temas edilmekteydi. ${ }^{21}$ Nitekim pişkeşe aynı zamanda "berât pişkeşiı" denilmekteydi. ${ }^{22}$

Farsça "hediye" anlamına gelen pişkeş, Osmanlı İmparatorluğu'nda padişah öncelikli olmak üzere sadrazamlara ve diğer devlet görevlileri ile hanedan mensuplarına alt makamlardan takdim edilen hediyeler için kuruluş döneminden beri kullanılan bir kavram olmuştu. Fakat İmparatorluk bürokrasisi geliştikçe ve bilhassa 17. yüzyılın sonlarına doğru pişkeş, daha çok nakdî ve belirli bir meblağ itibarıyla ödenen bir yükümlülük hâline gelmişti. ${ }^{23}$ Patriklerin ve metropolitlerin ödedikleri pişkeşler de zaman içerisinde kurumsallaşmıştı. Fatih Sultan Mehmed zamanında Patrik Simeon'un hazineye 2.000 filori ödemesi gerektiği defterdar tarafindan kendisine bildirilmişti. Bu durum yani pişkeşin sultana değil de hazineye ödenmesi pişkeşin kurumsallaştığının işareti idi. ${ }^{24}$ Yine Piskopos Mukataası Kalemi’nden çıkan defterler de kurumsallaşmanın boyutlarını göstermesi açısından önemlidir. ${ }^{25}$

İncelediğimiz dönem itibarıyla Trabzon metropoliti olan rahiplerin de beratlarını almadan önce, Fatih Kanunnamesi'nde de görüldüğü üzere bir kanun hükmündeki pişkeşi ödedikleri görülmekteydi. Bundan sonra ancak vazifelerini icra edebilirlerdi. Nitekim beratlarda, pişkeşin ödenmesinden sonra metropolitin vazifeleri bildirilmekte idi. Buna göre İksanofon'un (Kenofon) "ollgelen âdet ve kânûn üzre ve âyinleri mûcebince" metropolit olmas1; Trabzon ve tevâbiinde olan piskoposlar, papazlar, keşişler ve "sâir kefere tâifesinin ulusu ve kiçisi"nin rahibi kendilerine metropolit bilmeleri ve metropolitliğe ait işlerde kendisine müracaat etmeleri emredilmişti. Kendisine bağlı papaz, piskopos, keşiş ya da kalugarya öldüğünde patriğe ait olan metrukâtının "kadimden olıgeldügi üzre" metropolit tarafından zaptedilmesi ve kimsenin müdahale etmemesi buyrulmuştu. Yine ölen ruhbanlar, ayinleri üzere "kilise fukarasına" ve patriğe her ne vasiyet ederler ise makbul olması da belirtilmişti. Ayrıca köy papazlarının metropolitin haberi yok iken kimseye nikâh kıymamaları gerekmekteydi. Piskoposları, papazları ve keşişleri, metropolit, ayinleri üzere "azl ve nasb” edecek ve buna da kimse müdahale etmeyecekti. Bir zimmî kadın kocasından kaçsa veya bir erkek karısını boşasa ya da biriyle evlense aralarına metropolitten başka kimse girmeyecekti. Kendi ayinleri üzere kiliseye ait olan bağ, bahçe, tarla, panayır, çiftlik ve değirmenlere, manastırlara, ayazmalara ve kiliseye vakfolan yerlere metropolit, daha öncekiler nasıl tasarruf etmişler ise aynı ile tasarruf edecekti. ${ }^{26}$

Yukarıda işaret edilen Kenofon'un beratından sonra Trabzon, Maçka, Canca, Sürmene ve Of kadılarına evâhir-i Rebiülevvel 1038 (18-27 Kasım 1628) tarihinde gönderilen hükümde, Kirilos adlı rahibin südde-i saadete gelip ${ }^{27}$ bundan önce zikrolunan kadılıklarda bulunan zimmî

${ }^{21}$ Ahmed Akgündüz, Osmanlı Kanunnâmeleri ve Hukukî Tahilleri: 1. Kitap Osmanlı Hukukuna Giriş ve Fatih Devri Kanunnâmeleri, Osmanlı Araştırmaları Vakfı Yayınları, İstanbul 2006, s. 406.

${ }^{22}$ Halil İnalc1k, "Ottoman Archival Materials on Millets", Christians and Jews in The Ottoman Empire, The Functioning of A Plural Society, (ed. B. Braude-B. Lewis), C. I, New York 1982, s. 448.

${ }^{23}$ Filiz Karaca, "Pişkeş", DİA, C. 34, İstanbul 2007, s. 294.

${ }^{24}$ Kenanoğlu, “'Ruhanî İltizam' Sistemi”, s. 82.

${ }^{25}$ Elimizde bulunan defterler 1641 tarihinden başlamakta olup 1837 yılına kadar devam etmektedir ve bu tarihte Piskopos Halifeliği Mukataası kaldırılmıştır. İnalcık, “Ottoman Archival Materials on Millets”, s. 441.

${ }^{26}$ T.S.S., 1821-4, 128/1.

27 Elbette bütün metropolit adayları bizzat kendileri İstanbul'a gitmemekteydiler. Trabzon'da Efrenc Hisarı Mahallesi'nde sakin Tanaş v. Taranol adlı zimmî, Trabzon zimmîlerinin metropoliti olan Nektaryo (Nektarios, 1689-1706) v. Lefter'i dava etmişti. Eski Trabzon metropoliti olup ölen Yanik (Yannis, 1665-1689) v. Yanol, beş sene önce hayatta iken Tanaş'a "benim tarafimdan Mahmiyye-i İstanbul'da patrik olan Nofto'ya (?) her ne mikdâr akçe olur ise vir ve medine-i mezbûre keferesinin metropolidliğini bana getür" diye "emr" etmiş ve Tanaş da bu "emr"e binaen Patrik'e kendi malından 100 esedî kuruş verip metropolitliği almıştı. Daha sonra metropolitliği Yanik'e "“arz etmek” için Trabzon'a geldiğinde onu ölü olarak bulmuştu. Yanik'in kethüdası ve mahkemede hazır bulunan Kiryaki v. Enam adlı keşişe “"arz” ettiğinde o da patrike verdiği 100 esedî kuruşu kendisinin ona vereceğini taahhüt etmişti. Tanaş, söz konusu meblağın ölen metropolitin terekesini elinde bulunduranlar tarafindan kendisine verilmesi gerektiğine dair de elinde bir ferman olduğunu belirtmişti. Bunun üzerine kethüda Kiryaki sorgulanmış ve Tanaş'ın iddialarını reddetmişti. Tanaş'dan delil talep edilmiş fakat o da delil getiremeyince Kiryaki'ye söz konusu 100 esedî kuruşu Tanaş'a ödeyeceğine dair taahhütte bulunmadığına dair yemin teklif 
taifesinin metropoliti olan İksanofon (Kenofon) adlı rahibin ölmesi üzerine yerinin boş kaldığı ve Asitane-i Saadet'te patrik olan Kirilos ${ }^{28}$ adlı rahip tarafindan metropolit adayı Kirilos'a bu görevin verildiği; "Mâliye tarafından berât itdirüp üzerinde olmağla elinde olan berâtı mûcebince zabt itdirilmek bâbında inâyet ricâ" ettiği ve bunun üzerine de işbu emrin verildiği bildirilmişti. ${ }^{29}$ Dolayısıyla metropolit tayinlerinde öncelikle ölen ya da azledilen bir metropolitin yerine İstanbul Rum Patriki bir aday belirlemekte, bu aday ödemesi gereken pişkeşi hazineye ödemekte ve eline bir berat verilmekte; bu berat ile birlikte de padişaha müracaat edilerek görev yerindeki kadılara kendisinin metropolit olduğunun ve metropolitlikten kaynaklanan yetkilerini kullanabileceğinin belirtildiği bir hüküm talep edilmekteydi. Bunun üzerine bir hükümle birlikte berat da kadıya gönderilmekte ve sicile kaydedilmekteydi. Nitekim Kirilos'un berat1 23 Rebiülevvel 1038 (20 Kasım 1628) tarihi ile Trabzon kadısına gönderilmişti ve pişkeş için de 10.090 akçe vermişti. ${ }^{30}$ Bunun yanında muhtemelen metropolitlerin berat alma sürecine "mübaşir" olarak Osmanlı bürokrasisi içerisinden bazı kişiler daha dâhil olabilmekteydi. Örneğin Dersaadet çavuşlarından Mustafa Çavuş, Trabzon metropoliti olan Kirmanos'u (Kirilos) dava etmişti. Bundan önce metropolitlik "zabtı" için Kirilos Asitane-i Saadet'te bulunduğu esnada "emr-i şerîf ile" Mustafa Çavuş mübaşirdi ve Kirilos 8.000 akçe ücret "kavl" eylemişti. Mustafa Çavuş "kavl”" eylenmiş olan meblâğın 2.900 akçesini alıp 5.100 akçesinin Kirilos’un zimmetinde kaldığını söylemişti; dolayısıyla bunu talep etmekteydi. Bunun üzerine sorgulanan Kirilos "ben ücret kavl iylemedim lâkin mukaddemâ metropolid olan Eksasol (Kenefon) nâm râhibin mahrûse-i İstanbul'da sâkin ... Ahmed Beşe'ye ve ba'zı kimesnelere deyni olmagın râhib-i mezkûru Asitane-i Sa'adet’e isâl için emr-i şerîf ile mezkûr Mustafa Çavuş mübâşir koşup yedi bin akçe ücret kavl iylediler meblâğ-1 mezbûru Trabzon'da siz edâyla biz dahi senin yedinde olan ve külli (?) edâ idelim dimesiyle taahhüd eyledim idi zikrolunan 7.000 akçeyi edâya taahhüd idüp 2.900 akçesin virdim 4.100 akçesi kaldı anı Ahmed Beşe'den alsun diyü 7.000 akçe ücreti virmeyi taahhüd iyledim" şeklinde beyanda bulununca kendisine bu meblağın ödenmesi tembih olunmuştu. ${ }^{31}$ Kirilos'un ifadesi mevzuyu karmaşık hâle getirse de Mustafa Çavuş'un iddiası metropolitlerin berat temin etmeleri esnasında mübaşir tayin edilen kişilere belli bir ücret "kavl" eyleyebildiklerinin bir göstergesi addedilebilir. Dolayısıyla bir tür "hizmet akçesi" olan "mübâşiriyye" alındığına hükmedilebilir. ${ }^{32}$ Patriklerin atanmasında da sadrazamlara verilen "câize"nin yanında "gayr-i resmî hediye bahası" ya da diğer adıyla "cevâiz" adıyla bir kısım ödemeler daha yapılmaktaydı. Ayrıca metropolitler de tayin olundukları görev mahalline vardıklarında ellerindeki berat ve emirleri şer'iye siciline kaydettirmekte ve "mürasele akçesi” adıyla bir meblağı ödeyip mürasele kâğıdı almaktaydılar. ${ }^{33}$

Metropolit Kenofon 9.800 akçe pişkeş verirken Kirilos 10.090 akçe vermişti. İnalcık'ın da belirttiği üzere pişkeşler her geçen gün artmıştı; bunda metropolit olabilmek için girilen rekabetin payı olmakla birlikte İmparatorluğun, resmî makamları artan sayılarda iltizâma vermesi ile birlikte de pişkeşlerin meblağları sürekli artmış ve devlet de bunları hazine için bir gelir kapısı olarak görmeye başlamıştt. ${ }^{34}$ Nitekim gerekçesi tam olarak anlaşılamamakla beraber

edilmiş; o da yemin edince Tanaş davayı kaybetmişti. T.Ş.S., 1861, 41/1. 16 Cemâziyelahir 1106 (1 Şubat 1695). Bu kayıttan beni haberdar eden Prof. Dr. Necmettin Aygün'e teşekkür ederim.

${ }^{28}$ 17. yüzyılda Katolik misyonerler, Osmanlı tebaası Ortodoksları papalığı desteklemeye ikna etmeye çalışıyorlardı. $\mathrm{Bu}$ durum patrikleri, Ortodoksluğu muhafaza etmek için birtakım faaliyetlere girişmeye itmişti. Bu girişimlere bir başlangıç olmak üzere Patrik Kirillos Lukaris, 1627 'de İstanbul'da Yunanca baskı yapan ilk matbaayı kutsamıştı. Matbaa Katolik karşıtı polemikler basıyordu. Fakat Fransızlar Osmanlı bürokrasisini ertesi y1l bu matbaayı sökmeye ikna ettiler. Bruce Masters, "Değişen Bir Dünyada Hıristiyanlar”, Türkiye Tarihi 1603-1839, (ed. Suraiya Faroqhi-çev. Fethi Aytuna), Kitap Yayınevi, İstanbul 2011, s. 333.

${ }^{29}$ T.S.S.S., 1825, 96/7.

${ }^{30}$ T.S.S.S., 1825, 97/2.

${ }^{31}$ T.Ş.S., 1825, 51/2. Evâil-i Safer 1038 (30 Eylül-9 Ekim 1628).

32 "Mübaşiriyye" hakkında bkz. Halil İnalcık, Devlet-i 'Aliyye: Osmanlı İmparatorluğu Üzerine Araştırmalar-IV, Türkiye İş Bankası Kültür Yayınları, İstanbul 2016, s. 50-51.

${ }^{33}$ Kenanoğlu, Osmanlı Millet Sistemi, s. 168-169.

34 İnalc1k, "Ottoman Archival Materials on Millets", s. 448. 
Kirilos'un beratı ve bu beratın gereklerinin icra edilmesi için gönderilen hükmün tarihinden hemen bir sene sonra yine Trabzon, Erzurum, Bayburt, Kovans (Koğans), Erzincan, Kemah, Kara Hisar ve Şiryan (Şiran) kadılarına gönderilen hükümde, Kirilos adlı rahibin daha önce Trabzon ve tevâbii zimmîlerine metropolit olup ölen Ksenefon (Kenefon) adlı rahip yerine İstanbul patriki Leperkos'un (Kirilos) mektubu üzerine metropolit tayin edildiği ve bu sefer 26 Muharrem 1039 (15 Eylül 1629) tarihinde âdet-i pişkeş için hazineye nakit olarak 10.290 akçe teslim edince kendisine berat verildiği ifade edilmişti. Gümüşhane köyleri olan Kürtün, Semuklu ve Yerman da metropolitin tasarrufunda olacakt1. ${ }^{35}$ Dolayısıyla bir sene sonra Kirilos'un verdiği pişkeşin miktarının arttığı görülmekteydi. Bunda, ileride görüleceği üzere metropolitliğin bu dönemde bir çekişme mevzuu olmasıyla birlikte rekabetin artmasının etkisi olabilirdi. Bir sene sonra yeniden açık arttırmaya girilmiş ve bu sefer de 200 akçe daha arttırarak Kirilos yine metropolitliği iltizâm etmiş olabilirdi. Ayrıca bu 200 akçe artışa karşılık olarak belki de daha önce iltizâmına dâhil olmayan Gümüşhane'nin üç köyü daha iltizâmına dâhil edilmişti. $^{36}$

Görülebileceği üzere Trabzon'da metropolit tayinleri bu dönemde ya ölüm sebebiyle ya da metropolitlikten feragat edilmesi münasebetiyle gerçekleşmişti. Yine metropolitlerin vazife yaptığı sürelere bakıldığında; 1580'lerden itibaren devlet makamları için "acımasız bir rekabetin" ve hazinenin her yeni atamada elde ettiği gelirlere mukabil cereyan eden hızlı bir atama ve aziller silsilesinin olduğu bilinmekte; ${ }^{37}$ fakat Trabzon metropolitlerinin görevde kalma sürelerinin nisbî uzunluğunun bu husustan ayrı durduğu müşahede edilmektedir. Bu durum metropolitlerin tayinlerinde ve azillerinde kısmî bir istikrar olduğuna işaret olarak değerlendirilebilir. Bunda İmparatorluk bürokrasisinin metropolit tayinlerine -normal şartlar altında- doğrudan müdahale etmemesi etkili olmuş olabilir. Zira ölen ya da feragat eden bir metropolitin ardindan metropolit adayı İstanbul'a gitmekte ve patrik tarafindan aday olarak belirlenip sonra yetki tevdiini gerçekleştirebilmek için Mâliye'ye pişkeş ödendikten sonra "emri şerîf" ile işlem tamam olmaktaydı.

\section{Metropolitlerin Vazifeleri ve Toplanan Vergiler}

Yukarıda Kenofon'un beratı üzerinden belli oranda metropolitlerin vazifelerine dair malumat verilmişti. Şimdi Kirilos'un beratında zikredilen vazifelerine bakarak meseleyi detaylandırmak mümkündür. 23 Rebiülevvel 1038 (20 Kasım 1628) tarihli beratta ${ }^{38}$ görüldüğ̈̈ üzere, Trabzon ve tevâbii ile "Gümüşhane piskopos ve tevâbi'i kazâlarından olan piskoposlar ve papaslar ve keşişler ve sâir kefere tâifesinin ulusu ve kiçisi” rahibi metropolit olarak bilip metropolitliğine müteallik işlerde kendisine müracaat edecekler ve "doğru sözünden" dışarı çıkmayacaklardı. Anlaşıldığı kadarıyla bu dönemde Gümüşhane de Trabzon metropolitliğine bağlı idi. Ayrıca Kirilos'un metropolitliğine müteallik bir piskopos, papaz, keşiş veya kalugarya öldüğünde "meskat-1 re'sinde" bilinen vârisi yok ise patrike ait 5.000'den az olan metrukâtını metropolit patrik için zaptedecek ve dışarıdan kimse mani olmayacaktı. Bilindiği üzere Yavuz Sultan Selim Kudüs'ü fethettiğinde Ermeni patrikine verdiği fermanda metropolit, piskopos, papaz ve bunların yamaklarının metrukâtlarına patrik tarafından el konacağ kayıtlıdır. Yine bu husus Kanuni'nin 1521 ve 1556 yıllarında çıkardığ fermanlarda aynıyla devam ettirilmiştir. Yavuz Ercan'in verdiği bilgilere göre bu durum IV. Mehmed'in 29 Mart 1649 tarihinde verdiği

\footnotetext{
${ }^{35}$ T.S.S.S., 1824, 32/1.

${ }^{36}$ Bununla birlikte sonraki süreçte kendi ihtiyarıyla feragat eden Kirilos'un yerine Patrik Kirilos'un mektubu üzerine metropolit tayin edilen Aytimos (Anthimos) adlı rahip ise âdet-i pişkeş için 1045 Cemâziyelevveli'nin 21. gününde (2 Kasım 1635) hazine-i âmireye nakit olarak 3.000 akçe teslim etmiş ve bundan sonra kendisine berâtı verilmişti. T.Ş.S., 1828, 158/2. 23 Cemâziyelevvel 1045. (4 Kasım 1635). Burada dikkati çekeceği üzere Aytimos adlı rahip oldukça düşük bir meblağda pişkeş ile metropolit tayin edilmişti. Bu düşüşün nereden kaynaklandığını belirlemek zordur; fakat genel itibariyle bu dönemde pişkeşlerin arttığı hesaba katılırsa kâtibin sehven bir yanlışlık yapmış olması da mümkündür.

${ }^{37}$ Colin Imber, "Hükümet, İdare ve Hukuk", Türkiye Tarihi 1453-1603, (ed. Suraiya Faroqhi-Kate Fleet, çev. Bülent Üçpunar), Kitap Yayınevi, İstanbul 2016, s. 301.

${ }^{38}$ T.S.S.S., 1825, 97/2.
} 
"tecdîd-i berât"da kısmen değişmiştir. Buna göre ölen ruhban zümresinin malları 5.000 akçeden az ise bağlı oldukları patrik tarafindan alınacak, 5.000 ve 5.000 akçeden fazla malları ise devlete kalacaktı. ${ }^{39}$ Metropolit Kirilos'un 20 Kasım 1628 tarihli beratından anlaşıldığı kadarıyla 1649 yılından önce Rumlar için bu usul yürürlüğe girmişti. ${ }^{40}$

Kirilos'un beratı üzerinden vazifelerine devam edilecek olursa, köy papazları metropolitin haberi yok iken nikâh câiz olmayan zimmîlere âyinlerine muhalif nikâh kıymayacaktı. Bir zimmî kadın kocasından kaçsa veya bir erkek karısını boşasa ya da biriyle evlense, aralarına metropolitten başka kimse girmeyecekti. Yine ölen rahiplerin, kendi ayinleri üzere, kiliseleri "fukarâsına" her ne vasiyet ederlerse makbul olması buyurulmuştu. Ayrıca rahibin metropolitliğine müteallik bağ, bahçe, tarla, panayırlara, manastırlara, çayırlara, çiftliklere, ayazmalara, değirmenlere ve sâir kiliseye vakfolan yerlere "bundan evvel ve bunun emsâli" metropolit olanlar ne şekilde mutasarrıf olagelmişler ise Kirilos da o şekilde tasarruf edecekti.

Kirilos'un beratından bir gün önce yani 22 Rebiülevvel 1038 (19 Kasım 1628) tarihinde Trabzon Kadısı ve sancakbeyi, Erzurum, Bayburt, Koğans, Kelkit, Erzincan, Kemah, Kara Hisar ve Şiryan (Şiran), Maçuka ve tevâbii kadılarına gönderilen hükümde, ${ }^{41}$ yukarıda zikredilen berattaki bilgilere ek olarak köylerin papazlarından biri öldüğünde kiliselerinde giydikleri kilise libaslarının ve kitapların metropolit tarafından kabzedilmesi emredilmekteydi. Bu hükümde ayrıca bilhassa metropolite subaşılar, voyvodalar, ümena ve züemânın ve erbâb-1 timârın karışmaması buyurulmuştu. Yine mîrî rüsûm tahsil ederken elinde olan beygirinin ve katırının ulaklara ve sair kapıkullarına aldırılmaması emredilmişti. Normal şartlar altında gayrimüslimlerin ata binmeleri yasak idi. ${ }^{42}$ Fakat ruhban zümresinin vazifelerini icra ederken ve bilhassa metropolitlerin mîrî rüsum toplarken ata binmelerine müsaade edilmekteydi. ${ }^{43}$ Bunun yanında metropolitler "cerr" için ve sair hizmetler için "azm-i rah" ettiklerinde, vardıkları yerlerde yakalı dolama ve başka elbiseler, yağmurluk, ak sarık, siyah serbend giyebilmekteydiler. Yine at binip tirkeş (ok kabı, sadak) kuşanabilmekte; harbe, mızrak ve tüfek taşıyabilmekteydiler. Bunların yanında metropolitin yanında olan adamlarından "tekâlif-i voyvoda haracı" talep edilirse menedilmesi istenmiş ve bu faaliyetler esnasında metropolitin adamlarının da rencide edilmemesi buyurulmuştu. Ayrıca metropolitler "sâir hânelerden birer rub“ akçe ala"caklar ve "dahi bir zimmî iki avret almayup alursa mezbûr metropolid olan def‘ ve ref" idüp hakkından gelüp ve bir zimmî bilâ şer'-i şerîf bir kız oğlan bâkireyi tasarruf iderse metropolid olan râhib yüz sikke filorisin almayınca âyin-i bâtılaları üzere zabt ve tasarruf olup ve dahi bir zimmî metropolide ve ademlerine" el kaldırırsa "şer'-i şerîf mûcebince ta 'zir ve darb-1 şedîd" eyleneceklerdi. ${ }^{44}$

\footnotetext{
${ }^{39}$ Yavuz Ercan, "Türkiye'de XV. ve XVI. Yüzyıllarda Gayrimüslimlerin Hukuki, İctimai ve İktisadi Durumu”, Belleten, C. XLVIII, S. 188, (1983), s. 1145.

${ }^{40} \mathrm{Bu}$ durum Gülnihal Bozkurt'un da dikkatini çekmiş ve 1586 tarihli bir fermandan örnek göstererek 5.000 akçelik sınırlamanın daha eskilere dayandığını belirtmiştir. Gülnihal Bozkurt, Gayrimüslim Osmanlı Vatandaşlarının Hukukî Durumu (1839-1914), Türk Tarih Kurumu, Ankara 1996, s. 15.

${ }^{41}$ T.S.S.S., 1824, 34/1.

42 “... Kefere taifesi ata binmeyüp ve samur kürk ve kalpak ve firengî kemha ve atlas giymeyüp ve avretleri dahi Müslüman tarzında ve üslûbunda gezmiyüp ve parus ferace giymeyüp mahasal libaslarında ve tarzı üslûblarında tahkir ve tezlil olunmak şer'an ve kanunen mühimmat-1 diniyyeden iken... (21 Şaban 1040/25 Mart 1631).” Ahmet Refik, Hicrî On Birinci Astrda İstanbul Hayatı (1000-1100), Devlet Matbaası, İstanbul 1931, s. 52.

${ }^{43}$ Kenanoğlu, Osmanlı Millet Sistemi, s. 370.

${ }^{44} \mathrm{Bu}$ hükümden bir sene sonrasina tarihlenen ve Trabzon, Erzurum, Bayburt, Kovans (Koğans), Erzincan, Kemah, Kara Hisar ve Şiryan (Şiran) kadılarına gönderilen hükümde yine Kirilos'un vazifeleri aynıyla sıralanmış, hükmün son kısmında ise ufak bazı ifade farklılıkları olmuştur: "...ve sâir hânelerden birer rub" akçe virdigi karyeleri dahi her ne hâne kezâlik birer rub' vireler ve dahi bir zimmî iki avret almayup alursa mezbûr murdarpolid olan def ' ve ref‘ idüp ve bir zimmî bilâ şer'-i şerîf bir bâkireyi tasarruf iderse modropolid olan rahib yüz sikke filorisin almayınca âyin-i muattafîleri üzere zabt ve tasarruf fî (?) olup ve dahi bir zimmî modropolide ve ademlerine el kaldırıb şer‘-i şerîf mûcebince ahz ve darb-1 şedîd eyleyeler.” T.Ş.S., 1824, 32/1. 26 (boş) 1039.
} 
Metropolitlerin bütün bu vazifeleri içerisinde bilhassa önemli olanı ise vergi toplamaktı. İnalcık'1n belirttiğine göre 17. yüzyılda kiliseye ait olmak üzere toplanan vergiler şunlardı: Mîrî rüsûm ya da mâl-1 mîrî, patriklik ve metropolitlik vergisi, zitiye, zarar-1 kassâbiye, tasadduk, ayazma ve ayasmos, manastır resmi, panayır ve nikâh vergisi. ${ }^{45}$ Macit Kenanoğlu'na göre de, "Patrikhanenin kendi âdetlerince cemaat mensuplarından aldıkları vergiler" olup mîrî rüsûm kavramını karşılamayan; fakat patrikhane, devlet tarafından kendisine tarh edilen maktu miktarı, topladığı bu vergiler ile karşıladığından aralarında bir "iltibas" meydana gelmiş olan vergiler de şunlardı: "zarar-1 kassabiye, zeytiye, tasadduk akçesi, panayır ve ayazma rüsumu, evvelki, ikinci ve üçüncü nikâhları, senevî her zimmî evinden mutad-1 kadîm üzere veregeldikleri birer rub" ve her papazdan birer altın patriklik rüsumu, yine senevî her zimmî evinden birer rub' ve her papazdan birer altın metropolitlik rüsumu ayrıca bazı zimmîlerin senevî mîrî rüsum mukabilinde verdikleri buğdaylar ve kiliselerine göre batkâları ve küllî ve cüzî rüsumat."46 Gerek İnalcık'ın gerekse Kenanoğlu'nun verdiği listeler hemen her dönemde bu vergiler geçerli imiş gibi bir izlenime yol açmaktadırlar. Belki de zikredilen vergiler çok büyük değişiklik olmadan uzun zaman aynıyla toplanmıştır. Fakat biz elden geldiği kadarıyla şer'iye sicillerine yansıdı̆̆ı biçimiyle bu vergilerin zikredildiği belgeleri kronolojik bir sıra ile vererek vergilerde bir değişimin var olup olmadığını anlamaya gayret edeceğiz.

Kimi zaman vergi toplama hususunda bazı eksiklikler baş göstermekte, bu durumda da patrik, metropolitin toplayacağı vergileri tahsil ettirmek için vekil gönderme yoluna başvurmakta idi. İşte böyle bir sorunun giderilmesi istikametinde 16 Zilkade 1028 (25 Ekim 1619) tarihli ve 2 Muharrem 1029 (9 Aralık 1619) tarihinde Trabzon Kadısına ulaşan hükümde, ${ }^{47}$ Patrik Timotyos, Dersaadet'e arz-1 hâl sunmuş ve Trabzon metropoliti olan İğnatyos (İgnatios) adlı rahibin 1028 Muharremi evâilinde (19-28 Aralık 1618) İksanofon (Kenofon) adlı rahip lehine metropolitlikten kendi isteğiyle feragat ettiğini ve "berâtın ihrâç idüp varınca zaman mürûr iyledüginden gayri” patriklik "mesâlihinden" olan mîrî rusûm, tasadduk akçesi, panayır resmi, nikâh ve sair metropolitlik mahsulünü tamamıla talep ve tahsil etmek için "kendi cânibinden" Papa Yorgi, Papa Todor, Efterol ve Anderya adlı kişileri vekil tayin ettiğini bildirmişti. Bunlar Trabzon'a vardıklarında eski metropolitin vekili Yasif ve belgede isimleri boş bırakılmış olan diğer rahiplerin "ahz" edilmesi ve yeni metropolit varınca "ma 'rifet-i şer'le yarar kefilleri alınması bâbında emr-i şerîf ricâ" edilmişti. Ayrıca metropolitlerin topladığı vergilerin patrike ulaşması için de yine vekil tayin edilmekte ve dahi bu vekiller arasında başka bir bölgenin metropoliti de bulunabilmekteydi. "İstanbul keferesi metropolidi" olan Kirilos, Dersaadet'e mühürlü mektup gönderip metropolit, piskopos, papaz, keşiş, gamnoslar ve sair zimmî taifesinin ödemeleri gereken mîrî rüsum, tasadduk akçeleri ve "defter mûcebince lâzım gelen bâkîlerin" tamamıyla tahsil etmek için kendi tarafından Ambiro adlı papazı ve bilfiil Niksar metropoliti olan Vendekdoz (?) adlı rahibi vekil tayin ettirmişti. Fakat vergilerin toplanması esnasında bazı rahipler zimmetlerine lazım gelen mîrî rüsum akçesini vermemek için "bizim va'demiz tamâm olmağa" on gün, yirmi gün veya bir ay vardır şeklinde nizâ edebilmekteydiler; hâlbuki mîrî rüsûmda "va"de" câiz değildi, dolayısıyla nizâ ettirmeden vergilerin toplanması gerekmekteydi. Bunun yanında vekiller "altı ay bir yerde sâkin olmadın" yanında olan adamlardan da "yuva haracı" talep ettirilmeyecekti. ${ }^{48} 29$ Recep 1038 (24 Mart 1629) tarihli hüküm ${ }^{49}$ ile Patrik Kirilos bu sefer de Amasya metropoliti Zerase (?) adlı rahibi vekil tayin ettirmişti. Patrikliğine ait vergi mükelleflerinde "şer' $\hat{\imath}$ almaları" olup ve geçen seneden dahi "hayli bâkîleri olmagın defter mûcebince şer"le müteveccih olanlardan" tamamıyla tahsil olunması gerekmekteydi. Eğer vermekte sorun çıkarırlarsa "sser "le" emlak ve erzaklarından tahsil ettirilecekti. Rahiplerden bazılarının mîrîye olan borcu için akçeleri olmaz

\footnotetext{
45 İnalc1k, "The Status of the Greek Orthodox Patriarch under the Ottomans", s. 422.

${ }^{46}$ Kenanoğlu, Osmanlı Millet Sistemi, s. 191.

${ }^{47}$ T.S.S., 1821-4, 130/3.

${ }^{48}$ T.Ş.S., 1822, 74/1. ts. (Bir sonraki hükmün tarihi evâhir-i Muharrem 1031/6-15 Aralık 1621).

${ }^{49}$ T.S.S.S., 1826, 61/3
} 
ve yerine "bedel-i kumaş ve esbâb" verirler ise uğradıkları yerlerde bac ve gümrük adıyla akçe talep ettirilmeyecekti. 4 Şevval 1043 (3 Nisan 1634) tarihinde de fiilen Konya metropolitliği yapan Avralker (?) adlı rahip vekil tayin edilmiş ve senevi mîrî rüsûm, tasadduk akçeleri, panayırları, nikâhları ve manastırları resmi ve ölen rahiplerin "mu'tâd-ı kadîm" üzere patrike ait olan terekeleri ve "defter mûcebince" lâzım gelen bâkîlerinin tahsil edilmesi ile vazifelendirilmişti. ${ }^{50}$ Bundan sonra 24 Zilkade 1045 (30 Nisan 1636) tarihi itibarıyla bu sefer kayıtta ismi boş bırakılan rahibin vekil olarak "şer" ve kanûn hasebiyle ve patrik mektûbu ve âyin-i âtılaları muktezâsinca" toplaması istenilen vergiler ise senevi mîrî rüsûm, tasadduk akçeleri, panayırları, nikâhları, manastırları resmi ve defter mûcebince icap eden bâkîleri ve sâir patriklik mahsulâtından ibaretti. ${ }^{51}$

Patrik Krilos'un döneminde tahsil ettirilen bu vergilerin ardından 18 Zilkade 1061 (2 Kasım 1651) tarihi itibarıyla vergilerin sayısında bir artış olmakta idi. Beylerbeyine, Trabzon ve Gümüşhane kadılarına gönderilen hükümde ${ }^{52}$ belirtildiğine göre Patrik Yanikos adlı rahip, zikrolunan kadılıklarda sakin papazların, keşişlerin ve sair zimmîlerin; Trabzon metropoliti olan Lavizirtos (Lavrentios) ve Gümüşhane metropolitinin ödemeleri gereken geçen sene ve bu seneden mîrî rüsûm, tasadduk ve hassa bostancllık tayin olunan mîrî kesim akçelerinden bu ana değin bir akçe vermeyip zimmetlerinde kaldığını haber vermişti. Patrik tarafindan vekil olan İstoyfe adlı zimmî, edası lazım gelen senevî mîrî rüsum, tasadduk akçeleri ve hassa bostancılara tayin olunan mîrî kesim akçeleri, panayırları, nikâhları, manastırları ve ayazmaları resmi ile ölen papazların, keşişlerin ve kalugaryaların "mu'tad-ı kadîm” üzere patrike ait olan cüzî ve küllî metrûkâtlarını ve "senevi alınugelen her kefere evinden on ikişer akçe ve her papasdan birer altun patriklik rüsumu ve yine her kefere evinden on ikişer akçe ve her papazın kilisesine göre metropolitlik mahsulün" "̈̈ ${ }^{33}$ toplayacaktı. Bu hükümden iki sene sonrasına ait 11 Ramazan 1063 (5 Ağustos 1653) tarihli hükme ${ }^{54}$ göre de Patrik Yankilos (Yanikos), Trabzon metropoliti Lavrendiyos (Lavrentios) ve Gümüşhane metropoliti olan Silvestro adlı rahibin metropolitliklerinde sakin "papasların ve Şüzeklerin (?)" ve sair zimmîlerin ödemesi gereken senevî mîrî rüsum ve tasadduk akçeleri ve hassa bostancılarına tayin olunan mîrî kesim akçeleri ve "zitiye ve imdâd (?) akçelerin" ve geçen seneden kalan bâkîleri ve panayırları, nikâhları, manastırları, ayazmaları ve ölen papazların, keşişlerin, kalugaryaların cüzî ve küllî metrûkâtlarını ve senevî alınagelen her zimmî evinden on ikişer akçe ve her bir papazdan birer altın patriklik rüsumu ve yine her kefere evinden on ikişer ve her bir papazdan birer altın metropolitlik mahsulatının toplanması için Kostantini adlı zimmînin vekil tayin olunup gönderilmesi için emr-i şerîf ricâ etmişti. Papazlar ve keşişler, mîrî rüsum vermekte muhalefet ederlerse "ba-dest" ettirilip ayinleri üzere saçları tıraş olunduktan sonra papazlıklara müdahale ettirilmeyecekti. Böylece hassa bostancılara ödenen akçeler, zitiye ve imdâd (?) akçeleri gibi vergiler sicillerde ilk defa bu dönemde görünmeye başlamışlardı. Bundan 10 sene sonra da vergiler hemen hemen aynı olmak üzere tekrarlanacaktı. 4 Muharrem 1074 (8 Ağustos 1663) tarihli hükümde, ${ }^{55}$ Patrik Diyosamoy, "senevî mîrî rüsûm zarar-ı kassabiyye ve tasadduk akçeleri ve nikâhları ve panayırları ve manastırları ve ayazmaları resmi ve her papazdan birer altun ve her zimmîden ona (?) on ikişer akçe patriklik rüsûmu ve yine her papasdan birer altun ve yine her zimmîden ona on ikişer akçe metropolitlik mahsûlü ve kiliselerine göre bâkîleri azlolunup firâr iden Filotiyos nâm metropolidin vekillerinin kabz iyledügi bin yetmiş üç senesinin bakâyâsından ve bin yetmiş dört senesine mahsûb olmak üzere mîrî rüsûmu" tamamen toplamak için Amasya metropoliti Peraşmos'u vekil tayin ettirmişti. Vekil, 1074 senesinin vergilerini tamamen alıp Eksarhos Metodiyos'un elinde bulunan 10.000

\footnotetext{
${ }^{50}$ T.Ş.S., 1828, 108/1

${ }^{51}$ T.S.S.S., $1828,154 / 3$.

${ }^{52}$ T.S.S.S., 1832, 86/4.

53 Piskopos mukataası kaleminde bulunan ve imparatorluk genelindeki kadılara gönderilen 1061 tarihli hükümde de vergiler aynı ile sıralanmışıı. BOA, Kamil Kepeci Piskopos Mukataası Kalemi Defterleri (KK.d), no: 2542, vr. $3 / 2$.

${ }^{54}$ T.S.S., $1834,60 / 2$.

${ }^{55}$ T.S.S.S., 1840, 29/1.
} 
akçeden "mâ‘dasının" muhasebesini görecek ve Gümüşhane piskoposu olan Eftemyos adlı rahibin zimmetinde olan mîrî rüsûm ve haracı da "kabz" edecekti. Son olarak ise 10 Muharrem 1075 (3 Ağustos 1664) tarihi itibarıyla mîri rüsûm, zarar-ı kassâbiyye, tasadduk akçeleri, nikâhlart ve ayazmaları resmi ve her zimmî evinden on ikişer akçe ve her papazdan birer altın patriklik mahsulü ve yine her zimmî evinden on ikişer akçe ve her papazdan birer altın ve kiliselerine göre nâmkâneleri (?) (bâkîleri olması gerek) ve metropolitlik mahsulünü, Trabzon metropoliti orada olmadığı için "mîrî metropolitleri" varıncaya kadar Patrik Diyosamoy tarafindan vekil tayin edilen Senitres adlı zimmî tahsil edecekti. ${ }^{56}$

Görülebileceği üzere 18 Zilkade 1061 (2 Kasım 1651) tarihli hükümden sonra toplanan vergilerin sayısında bir artış olmuştu. Bu durumun, vergilerin o tarihlerde ihdas edilmesinden mi yoksa kâtiplerin vergileri daha tafsilatlı yazmaya başlamalarından $\mathrm{m}$ kaynaklandığını belirlemek zordur. Fakat bizim incelediğimiz belgelerde gerek İnalcık'n gerekse Kenanoğlu'nun verdiği listedeki vergiler 1650 yılından sonra görülmekteydi. Bunun yanında zikredilen listelerde ismi geçmeyen ve okunuşundan tam emin olmamakla beraber "imdâd (?) akçesi" adı altında bir vergi daha toplandığ 1 anlaşılmaktaydı. Bilindiği üzere İmparatorluk bürokrasisi, 17. yüzyılın ilk yıllarında savaşlardan kaynaklanan maddi sıkıntıları aşmak için varlıklı kimselerden yüksek meblağlı borç almaya başlamıştı. Bu kişiler de verdikleri borca mukabil sonradan reayadan vergi toplarlardı. Bu vergiler "imdâdiyye" ve "imdâd-1 seferiyye" olarak adlandırılmıştı. ${ }^{57}$ Girit Harbi'nin (1648-1669) cari olduğu bu dönemde İmparatorluk belki de gayrimüslimlerden "imdâd akçesi" nâmında vergi toplamışt. ${ }^{58}$

\section{Metropolitlerin Vazifelerini Yaparken Karşılaştıkları Bazı Sorunlar}

Yukarıda beylerbeyilere ve kadılara gönderilen hükümlerde vergi toplarken ruhban zümresinin birtakım sorunlarla karşılaşabildikleri; dolayısıyla bunların bertaraf edilmesi gerektiği hususunda bazı emirler sâdır olduğu görülmüştü. Söz konusu sorunların merkeze iletilmesinde metropolitlerin rolü olduğu anlaşılmaktaydı. Nitekim Trabzon kadısına 23 Cemaziyelevvel 1045 (4 Kasım 1635) tarihinde gönderilen hükümde, Trabzon ve tevâbii zimmîlerinin metropoliti olan Antimos'un (Anthimos) Dersaadet'e gelip arz-1 hâl sunduğu ve metropolitliğine ait zikrolunan kadılıklarda sakin piskopos, papaz, keşiş ve sair zimmîlerden vergileri toplamak istediğinde bazı beylerbeyi voyvodaları ve sair subaşıları ve iş erlerinin rencide ettikleri bildirilmekteydi. Yine kendisi mîrî rüsum toplarken bazı kimseler gelip "celb-i mâl" için sen bize sövdün ve "oğlanımız ayarttın" veya sana "karz akçe" verdik diye üzerine "şer"an" bir nesne sabit olmadığı hâlde rahatsız etmekteydiler. Tehlikeli yerlerden emniyet içerisinde geçmek için elbiselerini değiştirdiğinde ve "def"-i mazarrat" için "silâh esbâbı" getirdiğinde züemâ, erbâb-1 timâr, sipâh, yeniçeri ve sâir ehl-i örf taifesinden bazı kişiler "sen libâsını tağyir iylemişsin ve alât-1 harb getürürsün" diye sorun çıkarmaktaydılar. Metropolitliğine dâhil bir papaz, keşiş veya kalugarya öldüğünde, patrike ait olan metrukâtına elinde olan berat ve kanun-1 kadim gereğince el koyduğunda, dışarıdan bazı kassam adamları ve gayrileri müdahale etmekteydiler. Azl ve nasba müstehak olan papazları ve keşişleri azl ve nasp eylediğinde bazı ehl-i örf taifesi aralarına girip ayinlerine muhalif reddolunan papaza papazlık ettirmekteydiler ve kendisinin marifeti yok iken köy papazları nikâh caiz olmayan "kefereye" nikâh kıymaktaydılar. Mîrî rüsum toplarken tasarrufunda olan beygir ve katırı bazı kapıkulları ve ulaklar elinden alıp ve altı ay bir yerde sakin olmadan "hilâf-1 âdet ve kanûn" yanında olan adamlarından "yuva haracı" talep etmekteydiler. Neticede mevzu eğer metropolitin dediği gibi ise bunlara engel olunması ve tekrar padişahın kapısına "gelmelü" eylememeleri emredilmişti. ${ }^{59}$ Nitekim metropolitlerin ya da patrik tarafından gönderilen vekillerin vergileri toplamas1

\footnotetext{
${ }^{56}$ T.S.S., 1842, 69/5.

${ }^{57}$ İnalc1k, Devlet-i 'Aliyye-IV, s. 53.

${ }^{58}$ Girit Harbi'nin Trabzon üzerindeki etkisi hakkında bkz. Kenan İnan, "Trabzon Kadı Sicillerinde Girit Seferi Hakkında Kayıtlar (1648-1669)”, Uluslararası Osmanlı Tarihi Sempozyumu Bildirileri (8-10 Nisan 1999), (haz. Turan Gökçe), Türk Ocakları İzmir Şubesi Yayınları, İzmir 2000, s. 295-309.

${ }^{59}$ T.S.S.S., 1828, 158/3.
} 
hususuna dair hükümlerin hemen hepsinde bu sorunlara dikkat çekilmekte ve bilhassa ehl-i örfün müdahalelerinin engellenmesi istenmekteydi.

Trabzon kadısına 23 Cemaziyelevvel 1070 (5 Şubat 1660) tarihinde gönderilen hükümde de Trabzon ve tevâbii zimmîleri metropoliti olan Filotos (Filotheos), Dersaadet'e adam gönderip şikâyette bulunmuştu. Bilfiil metropolitliğine müteallik zikrolunan kadılıklarda sakin papazlar, keşişler ve sair zimmîlerin ödemeleri gereken vergileri toplamak istediğinde, bazı beylerbeyi ve sancakbeyi voyvodaları ve subaşıları ile sipah, yeniçeri ve sair ehl-i örf taifesi "hilâf-1 şer"-i şerîf ve kadîmden olıgelmişe muhâlif ve yedinde olan berât-1 hümâyuna mugâyir" müdahale ve rencide etmekteydiler. Metropolitliğine dâhil bir piskopos, bir papaz, bir keşiş veya bir kalugarya öldüğünde patrike ait olan metrukâtını kabzettiğinde beytü’l-mâl ve kassam adamları mâni olmaktaydılar. Ayrıca ayinlerine muhalif "vaz' iden" piskopos, papaz ve keşişleri ayinleri üzere azleylediğinde "haricden" bazı kimseler araya girip reddolunan papazlara geri "fuzûlî" papazlık ettirmekteydiler. Kendisinin bilgisi yok iken köy papazları nikâh câiz olmayan kefereye nikâh kıymaktaydılar. ${ }^{60}$

Bunların yanında Hıristiyan tebaadan bazı kimselerin metropoliti haksız yere ehl-i örfe gammaz ederek vazifesini yapmasına mani olabildikleri anlaşılmaktaydı. Metropolit Lavrendi, mahkemede, Trabzon'da Çömlekçi Mahallesi sakinlerinden Venyamen (?) v. Paskal (?) adlı Hıristiyanı dava etmişti. On gün önce Venyamen, "ben mahrûse-i Kostantiniyye'de ve tevâbi'inde perâkende olan keferenin patrigâhı (?) olan Payos nam râhibin vekiliyim patrik-i merkûmun Trabzon metropoliti olan Lavrendi nâm râhibde 70.000 akçesi vardır" diye Metropolit Lavrendi'yi ehl-i örfe gammaz etmiş ve hapsettirmişti. Ayrıca 200 kuruşunu da aldırmıştı. Vanyemen ise sorgulandığında bunu inkâr etmiş ve metropolitten delil talep edilmişti. Bunun üzerine Mustafa Çelebi b. Küçük Ali Beşe ve "Nasarî tâifesinden” Nikola v. Lefter adlı kişiler, gerçekten Venyamen'in Lavrendi'yi haksız yere ehl-i örfe gammaz ettiğini ve diğer hususların da doğru olduğunu ifade etmişlerdi. Neticede metropolitin söz konusu mevzuya dair elindeki fetva gereğince de 200 kuruşu Venyamen'in Lavrendi'ye ödemesine karar verilmişti. ${ }^{61}$ Dolayısıyla gayrimüslimler kendi metropolitlerine sorun çıkarabilmekteydiler. Bunda kimi zaman metropolitliğin bir çekişme konusu olması da etkili oluyordu. Yani mevcut metropoliti vazifesinden ederek onun yerine metropolit olma isteği bazı gayrimüslimleri bu gibi usulsüz hareketlere sevk ediyordu; bu durumu da ehl-i örf ile bağlantılandırarak ellerini daha bir güçlendiriyorlardı. Trabzon'da sakin Lefter adlı zimmî geceleyin "hevâsına tâbi nice eşkıya" ile Trabzon metropoliti olan Yerasmos (Gerasimos) adlı rahibin evine gelip "k1z isteyüp" metropolit de, "sabah (?) görelim müstehaklı virelüm" demişti. Ertesi gün Lefter, metropoliti bazı ehl-i örfe gammaz edip üç-dört bin kuruş parasını sebepsiz almıştı. Bundan sonra Lefter adlı "şak̂̂", İstanbul'a varıp Yerasmos'un metropolitliğini almak için "tâlib" olmuştu. Bu esnada "birkaç defa hadise (?) olup şer'-i şerîfe da'vet olundukda" birtakım kimselere istinat edip mahkemeye gelmemişti. Metropolit Yerasmos bazı hizmet ile ordu-yı hümâyuna gelince Lefter, "Asitâne-i saâdetten bir tarîkle" metropolitliği almış ve Trabzon'a varıp "hevâsına tâbi" Ağyadmor adlı zimmî ile yine ehl-i örfe gammaz etmiş; Yerasmos'un evinde olan mallarını ve erzakını yağmalamış ve yine reayaya da zulmetmişti. Dolayısıyla "fesâd ve şekâvetten hâlî olmadıkları" için "ele getürülüp kayd ve bend ile ordu-yı hümâyûna" gönderilmesi Trabzon beylerbeyine ve kadısına 24 Cemaziyelevvel 1019'da (14 Ağustos 1610) gönderilen hükümde emredilmişti. ${ }^{62}$

\section{Metropolitlerin Usulsüzlükleri}

17. yüzyılda ehl-i örf taifesinin reaya üzerinde bilhassa vergi nokta-i nazarından kurmuş olduğu baskıya metropolitlerin de kendi zaviyelerinden dâhil olduğu görülmekteydi. Bunda metropolitlik müessesinin bu dönemde bazı rahipler arasında bir çekişme mevzuu olmasının da

\footnotetext{
${ }^{60}$ T.S.S.S., 1838, 15/3.

${ }^{61}$ T.Ş.S., 1834, 35/5. Evâsıt-1 Zilhicce 1064. (23 Ekim-1 Kasım 1654).

${ }^{62}$ BOA, Mühimme Defterleri (MD), no: 79, s. 381, kayıt no: 972.
} 
etkisi vard1. Metropolitliğin kendilerine ait olduğunu iddia eden kişiler bu çekişmenin bedelini reayaya ödetiyorlardı. 12 Şevval 1019 (28 Aralık 1610) tarihli bir hükümde görüldügü üzere Trabzon'un zimmî taifesi Divan-1 Hümayun'a arz-1 hâl gönderip şikâyetçi olmuşlardı. Trabzon metropolitliği hususunda Yerasmos adlı rahip ile belgede ismi boş bırakılmış olan rahip arasında bir nizâ söz konusu idi. Muhtemelen bu kişi yukarıdaki kayıtta Yerasmos'un başına bela olan Lefter idi. Her iki rahip de metropolitlik iddiasında idi ve dolayısıyla "fukarâya gâh mezbûr Yerasmo ve gâh merkûm râhib tekâlif teklîf idüp üzerlerine lâzım olan ayineyi tekrar alup" sürekli zulmetmekte idiler. Dolayısıyla hangisinin beratı ve temessükâtı sonraki tarihli ise metropolitliğin ona verilmesi için hüküm rica etmişlerdi. ${ }^{63}$

Gerçekten daha önce de Yerasmos ve Lefter karşı karşıya gelmişlerdi. 28 Muharrem 1019 (22 Nisan 1610) tarihli hükümde Trabzon metropoliti Yerasmos ile Lefter adlı zimmînin dava ve nizaları olup meclis akdedildiği ve ahvallerinin ayan-1 vilayetten sual olunduğu belirtilmekteydi. Ahali-i vilayet ve sair reaya ise Lefter'den rıza ve şükran üzere olduklarını; fakat metropolitin daima zimmî taifesinin birçok emval ve erzakını alıp zulmettiğini belirtmişlerdi. Bunun yanında Müslümanların din ve imanlarına da "şetm" etmekte idi. Her surette izalesinin lazım olduğuna dair, kendisine itimat edilen kişilerin şehadetleri sicil ve hüccet olunmuştu. ${ }^{64}$ Fakat ilginç bir şekilde aynı tarihlerde bu sefer de Trabzon'da ve etrafta olan papazlar ve sair zimmî taifesi, "fesâd" ile meşhur olduğunu iddia ettikleri Lefter' in kendi "hevâsına tâbi" "birkaç zimmî ile Metropolit Yerasmos adına keşişlerden, papazlardan, piskopos ve sair zimmîlerden ziyade akçe aldığını belirtmişlerdi. Bununla birlikte onların ifadesine göre Metropolit Yerasmos "kendi hâlinde olup zulm ve te'addisi olmayup mezbûra her ne verdik ise kendi rızâmız ve elimiz ile virüp mezkûr Lefter nâm zimmî kuyumcu olup mühür peydâ idüp ve gelen harâccılar yanına varup gammaz ve izlâl itmekle her ispençeden birer filori ve ikişer guruş ve her harâcdan üçer yüz ve dörder yüz akçe aldırup ve her ne bid'at olursa mezbûr Lefter'in re'yi ile olup bundan akdem iki def' a taş gemisine konulup nice zeman taş gemisinde olduktan sonra mal kuvvetiyle halâs olup kimesneye zulm ve teaddi eylememek için tevbe ve istiğfâr iylemiş iken girü kendi hâlinde olmayup" metropolite iftira atmışt1. ${ }^{65}$ Kimin haklı olduğuna karar vermek zor görünmekle birlikte başka kayitlarda da metropolitin ve hatta oğlunun usulsüzlüklerine işaret edilmekteydi. Metropolit Yerasmos'un oğlu Eksanol adlı zimmî, sipahi şeklinde kızıl bayrak ile gezmekte, ayrıca yeniçeri keçesi giyip yeniçeri şeklinde de gezip reayaya zulmetmekteydi. ${ }^{66}$ Ayrıca 1 Rebiülahir 1019 (23 Haziran 1610) tarihli hükümden anlaşıldığı kadarıyla Metropolit Yerasmos reayadan bazı nesneler alıp zulmetmişti. ${ }^{67}$ Hatta aşağıda görüleceği üzere bir yeniçeriyi şarap içme bahanesi ile kandırıp kendi dininin propagandasını yapmıştı. Elbette Yerasmos'un zikredilen icraatları Lefter'i aklamamaktadır. Zira metropolitlik hususunda aralarında cari olan çekişme her ikisini de usulsüzlüğe sevk etmiştir diyebiliriz. Fakat mahkemede her ikisi hakkında da iyi hâllerine dair reayanın bir kısmının şehadet etmeleri, Lefter ve Yerasmos eksenli bir hizipleşmenin göstergesi idi ve muhtemelen her ikisinin taraftarları bağlı bulundukları hizip başı lehine mahkemeyi manipüle etmeye çalışmışlardı. Zira kimin taraftar olduğu kişi metropolit olursa o grup muhtemelen daha rahat edecekti. Bununla birlikte her hâlükârda zarar gören reaya olmaktaydı.

Yerasmos ve Lefter'in neden oldukları sorunların yanında, bu sefer de Trabzon metropoliti olan Sasol adlı papaz "kendü hâlinde olmayup fukarâya zulm ve te 'addi" eylemişti. $\mathrm{Bu}$ nedenle Sasol'un Rodos adasına sürülmesi için emir çıkmışken sabık metropolit buna itaat etmemiş ve hatta yeniden metropolitliğe müdahale etmişti. Bundan sonra metropolitlikten yine

\footnotetext{
${ }^{63}$ BOA, $M D$, no: 79 , s. 413 , kayit no: 1033.

${ }^{64}$ BOA, $M D$, no: 79 , s. 97 , kayit no: 243.

${ }^{65}$ BOA, $M D$, no: 79, s. 99, kayit no: 248. 28 Muharrem 1019 (22 Nisan 1610).

${ }^{66}$ BOA, $M D$, no: 79, s. 147, kayıt no: 367. 20 Rebiülevvel 1019 (12 Haziran 1610).

${ }^{67}$ BOA, $M D$, no: 79 , s. 335 , kayit no: 843 .
} 
el çekmez ise Rodos Adası'na sürülmesi ferman olunmuş (5 Şevval 1022/18 Kasım 1613) ve varıp teslim olduğuna dair beylerbeyinden temessük alınması buyrulmuştu. ${ }^{68}$

Reaya ve metropolitleri karşı karşıya getiren bir diğer husus da terekelerdi. Trabzon sakinlerinden Zestosol v. Manoşak adlı zimmî, Trabzon metropoliti Kirilos adlı rahipten davacı olmuştu. Buna göre ölen babası Manoşak'ın muhallefatına Kirilos "vaz'-1 yed" etmiş ve Zestosol'a müdahale ettirmemekteydi. Kirilos cevabında, Manoşak'ın sonradan piskopos olduğunu ve "âyin-i bâtıla"ları üzere piskopos ve sair ruhbanın terekesinin patriklerine "râci" " olduğunu, buna dair de elinde berat ve emr-i şerif bulunduğunu belirtmişti. Bunlara bakıldığında piskopos ve rahip olanların sadece giydiği libasların patrike ait olduğu anlaşılmış, bu nedenle geriye kalan kısmından el çekilmesi gerektiği ve sair muhallefatının Zestosol'a verilmesine hükmedilmişti. ${ }^{69}$

Metropolitler, kendilerine bağlı piskoposlukların mahsullerini belli sürelerle muhtemelen peşin bir meblağ karşılığı "tevfîz" etmekte idiler. Fakat zaman zaman kendi yapmış oldukları sözleşmeye riayet etmeyerek piskoposluk mahsulünü bizzat kendileri toplamaya çalışmaktaydılar. Maçka Nahiyesi'ne bağlı Livera adlı köyden Baba adlı rahibin vekili kardeşi Avram, Trabzon metropolitini dava etmişti. Buna göre "âyin-i bâtılamız üzere metropolid-i mezbûrun 'uhdesine lâzım gelen piskoposluk akçesi mukâbelesinde Bayburd Kazâsı'nın bir yıllık piskoposluğun karındaşım nâm zimmîye tefvîz idüp yedine temessük virmişken medropolid-i mezbûr yine varup kazâ-i mezbûrun piskoposluk mahsûlünü ahz ve kabz itmegin”, Avram, kardeşinin hakkını talep etmişti. Neticede metropolitin hatasını kabul etmesiyle birlikte davayı Avram ve kardeşi kazanmıştı. ${ }^{70}$

Patrikliğin Hassa Bostancılar Ocağı ile olan münasebeti de ${ }^{71}$ kimi zaman metropolitlere yansımakta ve bazı problemler ortaya çıkmaktaydı. İstanbul'da Hassa Bostancılar kethüdası olan Ahmed Ağa'nın vekili olan Ali Çelebi, Trabzon zimmîlerinin metropoliti olan Kirilos'dan davacı olmuştu. İstanbul patriğinin Kirilos zimmetinde olan panayır ve tasadduk akçeleri ve lâzım gelen diğer ödemelerden hâsıl olan borç, Ahmed Ağa'ya 140.000 akçe olarak havale edilmiş ve o da bunu almaya Ali Çelebi'yi vekil eylemişti; dolayısıyla Ali Çelebi, vekâleti hasebiyle bu parayı talep etmekteydi. Metropolit cevabında, metropolit rüsumundan ve tasadduk akçesinden zimmetinde bir akçe dahi olmadığını, lazım gelen "maktû'unu" her yıl patriğe verdiğini ve elinde tezkeresi olduğunu, ayrıca bundan başka Trabzon metropolitliğine bağlı olan Gümüşhane, Şiryan (Şiran), Bayburt ve Kovans (Koğans) kadılıklarına müdahale eylemediğini; zimmetinde bir akçe vereceği olmadığını söylemiş ve bu şekilde kayıtlara geçmişti. ${ }^{72}$ Tabii bu

\footnotetext{
${ }^{68}$ BOA, $M D$, no: 80, s. 192, kayit no: 483.

${ }^{69}$ T.Ş.S., 1827, 31/9. Evâil-i Şabân 1040 (5-14 Mart 1631).

${ }^{70}$ T.S.S.S., 1828, 28/3. Evâsit-1 Receb 1043 (11-20 Ocak 1634)

${ }^{71}$ 1641-1651 yılları arasındaki kayıtlara göre Rum patriği 20.000 kuruş pişkeş ödüyor ve bostancılara her gün 105 okka et sağlıyordu. Kenanoğlu, Osmanlı Millet Sistemi, s. 187. 1686 yılında ise aynî olarak et sağlama usulü kaldırılmış ve et alımı için her ay bostancıbaşılara 33.333 akçe nakit verilmesi karara bağlanmıştı: "Âsitâne kâimmakâmı Vezir Receb Paşa'ya ve Hassa Bostancıbaşı (boş) dâme mecdehûya hüküm ki hâlâ İstanbul ve tevâbi‘i vilâyetlerinde sâkin Rum keferesi patriki olan kıdveti muhtâri’l-milleti’l-mesihiyye Diyonisyos nâm râhib ordu-yı hümâyûnuma arz-1 hâl sunup zikrolunan patriklik tevcîh olundukda kadîmden cânib-i mîrîye virilügelen on yük akçe sâdır olan hatt-1 hümâyûn-1 șevketmakrûn ve fermân-1 'âlișân ile ref" olunup meblağ-1 mezbûr mukâbelesinde Hâssa Bostancılar Ocă̆ı'na beher yevm yüzer vukiyye lahm virmek üzere patriklik-i mezbûr kendüye tevcîh ve minvâl-i meşrûh üzere berât-1 âlişân virilmegin zikrolunan lahmın bahâsı içün beher mâh hâssa bostancıların orta eskilerine veyâhûd bostancıbaşılara otuz üçer bin üç yüz otuz üçer akçe virilüp yüzer vukiyye eti kendiler alup meblağ-1 mezkûrdan ziyâde taleb olunmayup ve lahm teklîfi ile rencîde ve remîde iylememeleri bâbında emr-i şerîf virilmek ricâ iylemegin husûs-1 mezbûr minvâl-i meşrûh üzere mâh be mâh otuz üçer bin üç yüz otuz üçer akçe lahm bahâ virilüp meblağ-1 mezbûrdan ziyâde taleb olunmayup lahmı bostancılar ocağı tarafindan kendüler alup aynî lahm talebiyle râhib-i mezbûr rencîde olunmamak bâbında emr-i şerîf virilmek ricâsına iftihârü'l-ümera' ve'l-ekâbir bi'l-fi'l başdefterdâr olan el-hâcc Ali dâme 'uluvvihu 'arz ve telhîs iylemegin telhîs mûcebince 'amel olunmak bâbında sâdır olan fermân-1 âlişân mûcebince fî 21 Safer 1097 (17 Ocak 1686) tarihinde emr-i şerîf virilmegin defter-i atîkde aynı ile işbu mahalle kayd olundu." BOA, Kamil Kepeci Piskopos Mukataası Kalemi Defterleri (KK.d), no: 2542, vr. 3/1.

${ }^{72}$ T.Ş.S., 1828, 129/10. Evâil-i Safer 1045 (17-26 Temmuz 1635).
} 
durum yerelde bazı sorunları da beraberinde getirmiş ve metropolit ve kendisine bağlı rahipler arasında Hassa Bostancılar kethüdası olan Ahmed Ağa'nın vekilinin "harc-1 râhı" ve diğer masrafları hususunda bazı anlaşmazlıklar ortaya çıkmıştı. Metropoliti Kirilos tarafından vekil olan Eksakasta (?) adlı zimmî, papazlardan Papa Yor, Papa Filibo, Papa Zöstol (?) ve gayrileri hakkında davacı olmuştu. Bundan önce İstanbul'da patrik tarafından metropolite 140.000 akçe "sâlyâne olunup" talep ve kabzına Bostancılar kethüdası tarafından adam gelip talep eylediğinde metropolitin zimmetinde akçe olmadığı için ahvâli arz olunup lazım gelen "harc-1 râh ve sâir mesârif-i mühimmeyi" adı geçen papazlar, Eksakasta'ya "sen harc ve sarf iyle biz sana mâbeynimizde tevzi“ idüp edâ ideriz" demişlerdi. Bunun üzerine Eksakasta bir miktar akçe harcamıştı. Sorgulanan papazlar ise cevaplarında Eksakasta'ya, sen harca, biz sana verelim demediklerini; bu hususta herhangi bir malumatlarının olmadığını söylemişlerdi. Bunun üzerine Eksakasta'dan delil talep edilmiş o da delil getirememişti. Bundan sonra papazlara yemin teklif edilmiş onlar da yemin edince Eksakasta davayı kaybetmişti. ${ }^{73}$ Nitekim İstanbul'da Hassa Bostancılar kethüdası olan Ahmed Ağa'nın vekili olan Ali Çelebi de Trabzon "keferesinin" keşişlerinden ve papazlarından Papa Yor, Papa Filibo, Papa Zöstol (?) ve gayrileri hakkında mahkemede ifade vermişti. Bundan önce patrik tarafindan Ahmed Ağa'ya 140.000 akçe Trabzon metropoliti olan rahipten havale olunmuş ve almaya geldiğinde metropolit zimmetimde akçe yoktur diye cevap vermişti. Durumun papazlardan sual olunup kaydedilmesini talep etmiş̧ti. Papazlar cevaplarında, metropolitin yedi senedir metropolitleri olduğunu, bu ana değin vermedikleri rüsumu tamamıyla kendisine verdiklerini söylemişlerdi. ${ }^{74}$

Böylece Hassa bostancılara havale olunan akçenin bir dizi sorunu beraberinde getirdiği anlaşılmaktaydı. Devamla, bu akçe münasebetiyle metropolit bir ara Bostancı elinden firar etmişti ve bu durumu da arasında niza olan papazlar aleyhine daha sonra bir çıkara tahvil etmeye çalışmıştı. Trabzon zimmîlerinin papazlarından Papa Yor, Papa Filibo, Papa Zöstol (?) ve gayrileri mahkemeye gelip metropolitleri olan Kirilos'un "havâlesi olan" Bostancı elinden firar ettiğini ve odasının açık kaldığını ifade etmișlerdi. Esbâbının zayi olmaması için "izn-i hâkim" ile odası mühürlenmiști; fakat daha sonra metropolit geldiğinde benim esbabım zayi olmuştur diye bu durumu papazlara "isnâd" etmişti. Adı geçen papazlar da mahkeme canibinden gidilip odaya bakılmasını talep etmişlerdi. Beylerbeyi tarafından Hüseyin Ağa ve mahkemeden de Mevlânâ Süleyman Efendi mahalle vardıklarında, odanın kapısının mühürlü olduğunu görmüşler ve kapıyı açıp baktıklarında da metropolitin eşyasının olduğu gibi durduğu anlaşılmıştı. Metropolit de bütün eşyasının mevcut yerinde olduğunu ve bir nesnenin zayi olmadığını ikrar etmişti. ${ }^{75}$ En nihayetinde Trabzon "keferesinin" papazlarından Papa Yor, Papa Filibo, Papa Zöstol (?) ve zimmîlerden Kaşbor ve gayrileri mahkemede metropolitlerinin bu ana dek zimmetlerinde ödemeleri gereken senevi mahsullerini tamamıyla aldığını söylemişler, metropolit de geçen senelerin mahsullerini papaz ve zimmîlerden tamamıla aldığını ifade etmişti. ${ }^{76}$ Böylece en azından resmî makamlar nezdinde metropolit ve kendisine bağlı papazlar arasındaki sorun çözülmüştü.

Metropolitlerin usulsüzlükleri ve kanuna mugayir hareketleri arasında bu dönemde bilhassa dikkati çeken bir mevzu da, dinlerinin propagandasını yapmak yasak iken firsat bulduklarında böyle bir yola tevessül edebilmeleri idi. Bir metropolitin bir yeniçeriyi içki içme teklifi ile kandırıp onu sarhoş ederek dininden döndürmeye çalışması, "hak din-batıl din" çekişmesinin Trabzon'daki bir numunesini teşkil etmekteydi. Batum beylerbeyi olan Ahmed Paşa, mektup gönderip Trabzon'da olan "kefere" taifesinin metropoliti Yerasmos (Gerasimos) adlı zimmînin, Trabzon'da yasakçılık yapan İsmail adlı yeniçeriye "şürb-i hamr" eylemek teklif

\footnotetext{
${ }^{73}$ T.Ş.S., 1828, 131/1. Evâsıt-1 Safer 1045 (27 Temmuz-5 Ağustos 1635)

${ }^{74}$ T.S.S.S., 1828, 131/2. Evâsit-1 Safer 1045 (27 Temmuz-5 Ağustos 1635).

${ }^{75}$ T.Ş.S., 1828, 131/5. Evâsit-1 Safer 1045 (27 Temmuz-5 Ağustos 1635).

${ }^{76}$ T.Ş.S., 1828, 131/6. Evâsıt-1 Safer 1045 (27 Temmuz-5 Ağustos 1635).
} 
edip "dîn bizümdür devr dahi bizümdür sizin dininiz bâtıldır" dediğinin sicil ve hüccet olunduğunu bildirmişti. ${ }^{77}$

$\mathrm{Bu}$ iş için bir yeniçerinin seçilmiş olmasında, her ne kadar 17. yüzyıla gelindiğinde devşirme sistemi bozulmuş ve birçok doğuştan Müslüman şahıs yeniçeriler arasına dâhil olmuş olsa da, gayrimüslim tebaanın zihninde hâlâ yeniçerilerin gayrimüslim bir menşeden geliyor olmaları düşüncesinin etkisi olmuş olabilir. Hatta 17. ve 18. yüzyıllarda bazı gayrimüslimler sosyal ve ekonomik birtakım sebeplerle ihtida edip nispeten sıkça yeniçeri zümresine dâhil olmaya başlamışlardı. Mahallî kilise ise bu eski gayrimüslim yeni Müslüman yeniçerileri çoğu zaman hâlâ kendi mensupları olarak tanımaktaydılar. ${ }^{78}$ Düşük bir ihtimal olmakla birlikte metropolitin İslam'1 kötüleyen ve kendi dininin "hak" olduğunu belirten propagandasını bu bağlamda değerlendirmek de mümkündür. Neticede metropolit hakkında şer'le lazım gelenin icra edileceğine dair hüküm gönderilmişti. Burada İslam'a hakaret etmiş olan metropolitin hükmü muhtemelen tazirdi. Zira Hz. Peygamber'e hakaret eden zimmînin Hanefî̀ fikhına göre tazir ve hapis ile cezalandırıldığı ve suçu tekrar işlediğinde ise ölüm cezasına çarptırılacağ bilinmektedir. ${ }^{79}$ Bununla birlikte Osmanlı uygulamasında din adamlarının daha çok sürgün ile cezalandırıldıklarına dair tespitler de bulunmaktadır. ${ }^{80}$ İster hapis isterse sürgün ile cezalandırılmış olsun bu olaydan sonra metropolit Yerasmos'un yerine İgnatios tayin edilmişti.

\section{Metropolitlerin Müslümanlarla Bazı Anlaşmazlıkları}

İncelediğimiz belgelerde s1k olmamakla birlikte Müslümanlar ve gayrimüslimler arasında bazı sorunların yaşandığı da görülmekteydi. Burada "millet-i hâkime" olarak Müslümanların baskın ve kimi zaman baskıcı unsur olduğunu çağrıştıracak bazı emareler söz konusu edilebilse de, aslında mevzunun sistematik bir baskı nokta-i nazarından ziyade kişisel bazı tasarruflar ekseninde değerlendirilmesi gerektiği anlaşılmaktadır.

Trabzon zimmîlerinin metropoliti olan Levrendiyo, zimmî tâifesiyle mahkemeye gelerek Habbaz İbrahim Beşe'den davacı olmuşlardı. Kadîiden "mevtâ"larını defnedegeldikleri kilise yerlerini İbrahim Beşe "bozup" kendi yerine dâhil edip bir de taş duvar örmüştü. Bunun üzerine sorgulanan Mehmed Beşe, zikrolunan kiliseyi otuz sene önce Beylerbeyi Mehmed Paşa'nın yıktığını, "taş kal'aya harç" ettiğini ve yerini kendisine sattı̆̆ını ifade etmişti. Daha sonra metropolitin ve zimmîlerin bu hususa dair ellerinde olan fetvaya bakılmış ve "kadîmî kilise yerini vâli-i vilâyet olan Zeyd Amr'a bey' iyledügi şer‘î olur mı? El-cevâb olmaz ehl-i zimmînin âyinleri üzere vakfdır ta 'arruz câiz değildir diyü buyurulmagın" İbrahim Beşe'nin cevâbı nâmeşru bulunmuştu. Dolayısıyla kilise yerine gidilmiş ve "cânib-i kıblesinde vâki" divar köşesinden taraf-1 şimâlinde olan eski divar temeline varınca iki haddi tarîk-i âm ve bir haddi merkûm İbrahim Beşe yerine ve bir haddi (boş) mülküne müntehi olan arz-1 hâliye kilise yeri olduğu zâhir ve mübeyyen" olunca, İbrahim Beşe'nin "tagallüben" çekdiği duvarın sökülmesine ve kilise yerini zimmîlerin tasarruf etmesine karar verilmişti. ${ }^{81}$

Bilindiği üzere Trabzon sulh yolu ile fetholunmuştu. ${ }^{82} \mathrm{Bu}$ durumda Müslümanların ibadetleri için şehirde bulunan bazı kiliseler camiye çevrilmiş; fakat genel itibarıyla kiliseler gayrimüslimlerin ellerinde bırakılmışlardı. Muhtemelen bu kiliselerden biri -Mehmed Beşe'nin ifadesine inanılacak olursa- Mehmed Paşa tarafından yıktırılmıştı. Paşa'nın 30 yıl önce kiliseyi

\footnotetext{
${ }_{77}^{70 A}, M D$, no: 79, s. 335, kayıt no: 844. 1 Rebiülahir 1019 (23 Haziran 1610).

${ }^{78}$ Nikolay Antov, "Kisve Bahası Arzuhalleri: Osmanlı Döneminde Balkanlarda İslamlaşma Sürecine Dair Bir Kaynak”, Kebikeç, S. 10, (2000), s. 100.

${ }^{79}$ Seda Örsten Esirgen, "İslam-Osmanlı Ceza Hukukunda Zimmîler”, Marmara Üniversitesi Hukuk Fakültesi Hukuk Araştırmaları Dergisi-Mehmed Akif Aydın'a Armağan, C. 21, S. 2, (2015), s. 208.

${ }^{80}$ Kemal Çiçek, “Osmanlılar ve Zimmler: Papa Pavlos'nun İslam'a Hakareti ya da Renklere İsyanı”, Klbrıs'tan Kafkasya'ya Osmanlı Dünyasında Siyaset, Adalet ve Raiyyet, Derya Kitabevi, Trabzon 1998, s. 144.

${ }^{81}$ T.Ş.S., 1831, 43/9. Evâhir-i Safer 1060 (23 Şubat-3 Mart 1650).

82 Kenan İnan, “Trabzon'un Fethi”, Öncesi ve Sonrasiyla Trabzon'un Fethi, (haz. İsmail Hacifettahoğlu), Trabzon Belediyesi Kültür Yayınları, Ankara 2001, s. 106-117.
} 
neden yıktırdığı belli değildi. Belki de kilise kadim bir kilise değil de "muhdes" yani fetihten sonra yapılmış bir kilise idi. Dolayısıyla fikhî hükümler gereğince bir yerde eskiden kalma (kadim) bir kilise yoksa ve buraya yeni bir kilise inşa edilmiş ise bunun yıktırılması normaldi. Yine kadim bir kilise de tamir edilirken aslına fazladan bir şey eklenmeden "üslûb-1 sâbık" üzere tamir edilmesi gerekirdi. Eğer bu kurala uyulmazsa fazladan yapılan yerler yıktırılırdı. Hatta bazı gayrimüslimler tamir etmek için aldıkları izne uymayarak kiliseye birçok yeni kısımlar ekleyebilmekte ve âdeta yeni bir kilise inşa etmekteydiler; bu gibi durumlarda da söz konusu kilise yıktırılabilmekteydi. Yine güvenlik gerekçesi ile (örneğin kilisede harp aleti bulunması) kiliseler yıkılabilmekteydiler. Kiliselerde yapılan kavga ve gürültülerden mütevellit de mescitlerde namaz kılmanın müşkül hâle gelmesi üzerine Müslüman ahali kilisenin yıkılması talebiyle kadıya müracaat edebilmekteydiler ${ }^{83}$ Bu gibi sebeplerden ötürü kilise Mehmed Paşa tarafından yıktırılmış olabilirdi. Zaten burada problemin kilisenin yıktırılması olmadığı anlaşılmaktayd. Nitekim metropolit ve yanındaki zimmîler de gayr-i hukukî bir şekilde yıktırılmış olan kiliselerinin yeniden inşası için mahkemeye müracaat etmiş değillerdi. Dolayısıyla kilisenin yıktırılması muhtemelen meşru bir dairede cereyan etmişti. Onların sorunu, kiliseden geriye kalan ve mezarlık olarak kullandıkları arazinin usulsüz bir şekilde Mehmed Beşe tarafından tasarruf edilmesi idi. ${ }^{84}$

Benzer bir durum 1583 yılında İstanbul'da cereyan etmişti. Eğrikapı haricinde bulunan Yahudi mezarlığından bir miktar arazi Hüseyin adlı bir kişi tarafından kendi arazisine dâhil edilmiş ve başka bazı Müslümanlar da mezar taşlarını alıp evlerine götürmüşlerdi. Bu münasebetle Yahudiler Divan-1 Hümayun'a müracaat etmişler ve neticede yapılan haksızlığın ortadan kaldırılması için defaatle fermanlar 1sdar edilmişti. Yahya Araz, kendisinin de istisnai olduğunu ifade ettiği bu olay münasebetiyle "Müslümanların bir kısmının yaptığı bu yağmalama gayrimüslimlerin değerlerine karşı ne kadar duyarsız olduklarının bir göstergesi olarak kabul edilmelidir. Mezarlık yağması, Müslümanların bir kısmının gayrimüslimlere ait "kutsal"ları sayg1 duyulacak bir değer olarak görmediğini ortaya koyar niteliktedir. $\mathrm{Bu}$ yağma, gayrimüslimlere yönelik dilsel ve sembolik aşağılamanın zaman zaman daha ileri boyutlara ulaştığını ya da eylemsel bir çehre kazandığını da göstermektedir" ${ }^{85}$ diyerek aslında istisnai olan bu mevzuyu genelleştirip Müslümanların gayrimüslimlerin "kutsal”larına saygı duymadığının bir belirtisi olarak değerlendirmektedir. Hâlbuki mesele Müslümanlıktan ziyade kişilerin şahsi tavırları ekseninde de değerlendirilebilir. Çünkü burada mesele mezarlığın Yahudilere ait olmasından ziyade daha çok maddi menfaat noktasında düğümlenmektedir. Zira Yahudilere bu olaydan önce Hasköy’de Sultan Bayezid vakfı toprağında yeni bir mezarlık yeri tahsis edilmiş ve buna mukabil Eğrikapı'daki eski mezarlık yerine ölü gömmeleri yasaklanmıştır. Dolayısıyla

\footnotetext{
${ }^{83}$ Kenanoğlu, Osmanlı Millet Sistemi, s. 289-292, 302. Bilindiği üzere 1856 Islahat Fermanı ile birlikte kiliselerin tamirine engel olunmayacağı ve yeni kilise yapımı için de Bâbıâli'den izin istenmesi gerektiği belirtilmişti. Bu bağlamda Akçaabat'ta yeni inşa edilen kiliseler hakkında bkz. Necmettin Aygün, "Akçaabat'ta Gayrimüslim Osmanlı Vatandaşlarının Kilise ve Mektep İnşaatları”, Dünden Bugüne Akçaabat, Akçaabat Belediyesi Kültür Yayınları, İstanbul 2014, s. 121-150.

${ }^{84}$ İncelediğimiz belgeler nispetinde bu gibi problemler ile oldukça az karşılaştığımızı ifade edilebiliriz. Elimizdeki bir diğer örnekte de Aya Filibo Kilisesi'nin içerisindeki meyve ağaçlarına müdahale edildiği görülmekteydi. Aya Filibo Kilisesi'nin "metropolidi" ordu-yı hümayuna arz-1 hâl etmiş ve zikrolunan kilisenin "taş divar havlusu" içinde bulunan meyve ve zeytin ağaçlarının Yavuz Sultan Selim Trabzon'da iken içinde sakin olan metropolite 160 sikke altına satılmış olduğunu ve yüz seneyi aşkındır kiliseye metropolit olanların mülkiyet üzere tasarruf ettiklerini söylemişti. Bunun yanında etrafı taş duvarla örtülü avlunun dışında bir miktar zeytinlik Hatuniye İmareti’nin vakfı olması hasebiyle öşr ve resm-i vakıf için alınmaktaydı. Hududu da vakfiyede belirlenmiş iken daha önce Hatuniye mütevellisi avlunun içinde bulunan zeytinlik ve meyve ağaçlarına müdahale etmek istemiş, o zaman İstanbul'da "müfettiş-i evkâf" huzurunda "murafa'â" olunmuşlar ve Hatuniye Vakfı'nın kati surette alakası olmadığı mahkeme tarafindan tespit edilerek mütevellinin müdahale etmemesi doğrultusunda hüccet verilmişti. Fakat bu doğrultuda emr-i şerif de gönderilmesine rağmen hâlâ vakfın mütevellisi müdahale etmekteydi. Dolayısıyla mütevellinin engellenmesine dair hüküm gönderilmişti. T.Ş.S., 1841, 23/2. 24 Safer 1082 (2 Temmuz 1671).

${ }^{85}$ Yahya Araz, Klasik Dönem Osmanlı Toplumunda Müslim Gayrimüslim İlişkileri Bağlamında Lise Tarih Ders Kitaplarında 'Öteki’ Sorunu, Dokuz Eylül Üniversitesi, Eğitim Bilimleri Enstitüsü Basılmamış Doktora Tezi, İzmir 2008, s. 181.
} 
bu durum muhtemelen beraberinde bir boşluğu getirmiş ve birtakım firsatçılar da bunu değerlendirerek mezarlıktan maddi menfaat temin etmeye çalışmışlardır. Aslında böyle bir fırsatçı, rahatlıkla bir Müslüman mezarlı̆̆ını da yağmalayabilirdi. Yani burada mesele, daha çok, mezarlığın Yahudi mezarlığı olmasından ziyade, çıkar temin edilebilecek bir yer olması ile alakalı gibi durmaktadır. Nitekim bir Müslüman olan Kuşçu Mehmed Ağa, İstanbul'da Cebecibaşı Mahallesi'nde bulunan ve "ashâb-1 kirâm hazerâtı zamânında vâki' olan muhâsara mevâzi‘i olduğundan gayrı belde-i tayyibenin Ebü’l-feth Sultân Mehmed Hân -tâbe serâhuzamânında vâki' olan muhâsara ve feth-i tâmmı vaktinde dahi mahall-i ma 'reke ve kıtâl olduğu kütüb-i tevârîhde mastûr ve ma 'lûm-1 sıgâr ve kibâr olmağla mekâbir-i ehl-i îmân" olan yere selhhane (mezbahane) yapmış ve hayvan pislikleri münasebetiyle "merâkıd-ı şühedâ" olan mezarlığı rahatsız etmişti. Bunun yanında "Ayvansaray'a giden yolun sağ tarafında bulunan "arsa kadîmden mekâbir-i müslimîn olup ve hâlâ mezâr taşları mevcûd iken, ol mevâzi“de bulunan çeyrekçi selhhâneleri tarafından mahall-i mezbûre ağıllar yapılıp, içinde koyun vaz' 1 ile mezâristânı telvîs edip ve odun yak"mışlardı ${ }^{86}$ Yine mezarlığa Müslümanlar tarafından yapılan saygisızlığa bir örnek olması açısından Mehmed b. Ahmed ve Ümmühâni bt. Abdullah'ın öğleden sonra "Edirnekapısı hâricinde vâki' mekâbir-i müslimîn içinde nazar-1 nâssa hafî bir mahalde oturup mu 'âmele-i fuhş ederler iken" subaşı tarafından yakalanmaları ve suçlarını itiraf etmeleri örnek gösterilebilir. ${ }^{87}$ Aynı minvalde Emine bt. Mustafa, Hatice bt. Abdullah ve Havva bt. Abdullah adlı hatunlar, kendilerine na-mahrem olan Ahmed b. Mustafa ve Mustafa b. Ali ile Eyüp’te "Câmi'-i Kebîr Mahallesi'nde vâki' mekâbir-i müslimîn üzerinde nazar-1 nâsdan hafî mevzi'de oturup mu‘âmele-i fuhş ederlerken” yakalanmışlardı. ${ }^{88}$ Dolayısıyla birkaç Müslümanın Yahudi mezarlığından taş çalmaları, Yahudilere ve genel itibarıyla bütün gayrimüslimlere karşı sistematik bir tavrın neticesi olarak değerlendirilemez kanaatindeyiz. Bunun yanında bu mevzuun neticelendirilmesinin yaklaşık üç sene sürmesinin Araz'ın ifadesiyle "yerel idarecilerin ihmali yorumuna ister istemez davetiye çıkarması" ise birden çok kişinin dâhil olduğu bu mevzuda soruşturmanın bütün detaylarına vâkıf olmadığımız için ancak spekülatif bir yoruma davetiye çıkarmaktadır. Zira bunun aksi istikamette gayrimüslimlerin kutsallarına ve ibadet yerlerine yapılan tecavüzlere izin verilmediğine dair Araz'ın "unique" örneğinden daha çok örneğimiz ${ }^{89}$ olması, spekülasyonun derecesini de arttırmaktadır.

Tabii bütün bu söylenilenlerden İmparatorluğun Müslüman halkının gayrimüslimlere karşı mütekâmil bir vaziyette saygı duydukları anlaşılmamalıdır. Cemal Kafadar'ın ifade ettiği üzere “...ulus devlet öncesi imparatorlukların en hayırhahının dahi üst veya alt kimliklere tamamıla lakayt durduğunu, resmî tarih inşası (gibi bir şey) dâhil çeşitli ideolojik ve idari aygıtlara başvurmadığını, 'dileyen dilediğine inanır, dilediği dille konuşur, yeter ki vergisini versin, sadakatten şaşmasın' genişliğinde bir tavır sürdürdüğünü iddia etmek mümkün değil.,"90 Hak din/batıl din ayrımı üzerinden şekillenen bir dünyada, seküler bir zihnin -olması gereken noktasında- her türlü inanç biçimine saygı duyması gerektiği hususu modern zamanlar ile başlatılabilir. Dolayısıyla geleneksel bir zihinden böyle bir tavır beklemek anakronik olur. Zira örneğin Müslümanlık ve Hıristiyanlık bağlamında her iki dinin mensupları da kendi dinlerini hak din olarak görmekteler, dolayısıyla biri diğerini batıl olarak addetmektedir. $\mathrm{Bu}$ nedenle normal şartlar altında birbirlerinin inanç biçimlerine ve bunun pratikteki görünümlerine saygı duyduklarını söylemek zordur. Nitekim Osmanlı İmparatorluğu bağlamında bu durum gayrimüslimlere yönelik kullanılan kavramlarda açıkça görülmektedir. Örneğin Müslümanlar

\footnotetext{
${ }^{86}$ İstanbul Kadı Sicilleri İstanbul Mahkemesi 24 Numaralı Sicil (H. 1138-1151/M. 1726-1738), C. 21, (ed. Coşkun Yılmaz, haz. Fuat Receb vd.), İSAM Yayınları, İstanbul 2010, hüküm no: 219, s. 300.

87 İstanbul Kadı Sicilleri Eyüp Mahkemesi 90 Numaralı Sicil (H. 1090-1091/M. 1679-1680), C. 31, (ed. Coşkun Y1lmaz, haz. Fuat Recep vd.), İSAM Yayınları, İstanbul 2010, hüküm no: 478, s. 402.

88 İstanbul Kadı Sicilleri Eyüp Mahkemesi 90 Numaralı Sicil (H. 1090-1091/M. 1679-1680), C. 31, (ed. Coşkun Y1lmaz, haz. Fuat Recep vd.), İSAM Yayınları, İstanbul 2010, hüküm no: 542, s. 448.

${ }^{89}$ Kenanoğlu, Osmanlı Millet Sistemi, s. 305.

90 Cemal Kafadar, Kendine Ait Bir Roma: Diyar-ı Rum'da Kültürel Coğrafya ve Kimlik Üzerine, Metis Yayınları, İstanbul 2017, s. 54.
} 
"vefât” ederken "kefere tâifesi helâk olmaktaydılar." ${ }^{91}$ Netice itibarıyla Müslim-gayrimüslim ilişkileri değerlendirilirken bunun zimmet hukuku çerçevesinde çizilmiş bir ilişki biçimi olduğu unutulmamalıdır ve bu istikamette söz konusu ilişkinin kadı mahkemesinin ve vereceği cezaların varlığı noktasında birbirine tahammül etmek şeklinde tezahür ettiği ifade edilebilir. Elbette bu tahammül etme hususunun yıllara yansıyan biçimi, hukuk çerçevesinde bir ortak yaşama kültürü de inşa etmiş ve "sosyolojik" olarak da kişiler bir diğer din mensubunun varlığııı ve yaşam pratiklerini "batıl" da olsa "kabul" etmişlerdir. Bilhassa Osmanlı İmparatorluğu'nun kuruluş döneminden itibaren gayrimüslim unsurlarla beraber yaşaması ve takip edilen "istimalet" politikası, belki de bir arada yaşama kültürünün en iyi örneklerinden birinin bu imparatorlukta görülmesine neden olmuştur. ${ }^{92}$

\section{Metropolitlerin Sosyo-Ekonomik Faaliyetleri}

Metropolitler elbette sadece ruhanî işlerle ve iltizâm siteminin gereği olarak yapmaları gereken vergi toplama işlemleri ile ilgilenmiyorlardı. Onların da sosyal ve ekonomik hayatın içerisinde birtakım faaliyetleri söz konusu idi; fakat ne yazık ki belgelerimize onların bu yönleri çok da yansımamıştı. Elimizde olan belgelerde sosyoekonomik hayatın içerisinde kendisine en çok rastlanan metropolit, 1619-1628 yılları arasında metropolitlik yapan Kenofon'du.

Kenofon'un ve babasının birtakım ticari faaliyetlerle uğraştı̆̆ını çağrıştıracak bazı belgeler bulunmaktadır. Rize sakinlerinden olup Dersaadet yeniçerilerinden Mehmed Beşe, Trabzon metropoliti olan Eksafol'u (Kenofon) Evail-i Cemaziyelevvel 1030 tarihinde (24 Mart 1621-2 Nisan 1621) dava etmişti. Daha önce metropolitin babası Yerasmos adlı rahibe Halep'ten gelirken 40 kuruş vermişti. Yerasmos ölmüş ve muhallefatı oğluna kalmıştı. Dolayısıyla Mehmed Beşe bu 40 kuruşu metropolitten talep etmekteydi. Kenofon bunu inkâr etmişti. Bunun üzerine Mehmed Beşe'den delil talep edilmiş, fakat o da delil getiremeyince metropolite babasının Mehmed Beșe'den Halep'ten gelir iken 40 kuruș almadığına dair yemin etmesi teklif edilince o da yemin etmiş ve davayı kazanmışt1. ${ }^{93}$ Kenofon'un babası da rahipti ve her ne kadar 40 kuruşun Yeniçeri Mehmed Beşe'den alındığ 1 ispat edilemese de, kayıttan anlaşıldığı kadarıyla Yerasmos Halep'e gitmişti. Ne için gittiği belli olmamakla birlikte bir ticaret kenti olan Halep'e bu bağlam içerisinde bir seyahat yapmış olması muhtemeldi.

"Prensip olarak din adamları kâr getirici işlerle uğraşmıyor"lardı; ${ }^{94}$ fakat Kenofon’un girmiş olduğu borç-alacak ilişkilerinde çuka bahasından borç almış olması, onun kumaş ticareti ile uğraşmış olabileceğine işaret sayılabilirdi. Eksafol (Kenofon) v. Yerasmos, Dergâh-1 mualla yeniçerilerinden Mustafa Beșe b. Ahmed'den evail-i Cemaziyelahir 1030 (23 Nisan-2 Mayıs 1621) tarihinden sene sonuna kadar ödenmek üzere "karz-1 şer'îden ve çuka bahâsından" 52.000 akçe borç almıştı. Bu borcun "zararına" ise mahkemeye gelen Kenofon'un oğlu Efkasend (?) kefil olmuştu. ${ }^{95}$ Borcun "zararına" kefil olunması da, bu borcun yapılacak bir ticaret için alınmış olabileceğini ve neticede bir "zarar" ortaya çıkarsa buna da oğul Efkasend'in kefil olduğunu düşünmeye sevk etmektedir. Nitekim ruhban zümresinin ticaretle uğraştığına dair elimizde başka örnekler bulunmaktadır. Bu istikamette Adana'da da bazı Hıristiyan rahiplerin çulha işiyle uğraştıkları görülüyordu. Böylece Goffman'ın da belirttiği üzere ruhban sadece dinî işlerle değil birtakım ticari faaliyetlerle de ilgilenmekteydi. Hatta 16. yüzyıl ve 17 . yüzyılda Batı Anadolu'da cereyan eden kaçakçılıkta ruhbanı görmek mümkündü. Kesendire Adası'nda

\footnotetext{
${ }^{91}$ Kafadar, Kendine Ait Bir Roma, s. 97.

${ }^{92}$ Trabzon'da 17. ve 18. yüzyıllarda Müslim-gayrimüslim ilişkileri hakkında bkz. Kemal Çiçek, "Şer'iye Sicillerine Göre Trabzon'da Müslim-Gayrimüslim İlişkileri”, Trabzon Tarihi Sempozyumu Bildirileri 6-8 Kasım 1998, (haz. Kemal Çiçek vd.), Trabzon Belediyesi Kültür Yayınları, Trabzon 2000, s. 235-243; Miraç Tosun, XVIII. Yüzyıl Trabzon'unda Cemaatler Arası İlişkiler, İstanbul Üniversitesi Sosyal Bilimler Enstitüsü, Basılmamış Doktora Tezi, İstanbul 2013.

${ }^{93}$ T.Ş.S., 1821-4, 85/6.

${ }^{94}$ Kenanoğlu, Osmanlı Millet Sistemi, s. 187.

${ }^{95}$ T.Ş.S., 1821-4, 89/8.
} 
yaşayan papazlar, öğüttükleri buğdayın ununu Gazanfer Ağa Evkafı'na göndermek yerine, 1613 yılında Aynaroz keşişlerine göndermişler ve bu un adaya gelen Batılı tüccara satılmıştı. ${ }^{96}$

Ruhban zümresinin ticari faaliyetlerde bulunabildiğinin bir diğer göstergesi de kendilerinden cizye alınması idi. Nitekim Trabzon'un ruhban zümresinden muhtemelen "kâr u kisbe kâdir" olmaları hasebiyle cizye alınmaktaydı. Patrik Kirilos, Divân-1 Hümâyûn'a başvurmuş ve Trabzon'da bulunan ruhban taifesinin 1045 senesine mahsup olan cizyesinin 100 altın olup Damyan adlı voyvodaya "der"uhde" olunduğunu belirtmişti. Bunun üzerine zikrolunan 100 altının Damyan voyvodanın adamlarına toplattırılmasi; metropolitten, vekillerinden ve adamlarından alıverilmesi için 25 Zilhicce 1044 (11 Haziran 1635) tarihinde kadıya hüküm gönderilmişti. ${ }^{97}$ Genel itibarıla literatürde ruhban zümresinin cizyeden muaf tutulduğu ifade edilmektedir; fakat belgelerden anlaşıldığı kadarıyla "kâr u kisbe kâdir" olmayan ruhban cizye ödememektedir. Dolayisiyla muafiyet bütün ruhban zümresini kapsamamakta, gelir elde eden ruhban Trabzon'dakiler gibi vergisini ödemekteydi. Kıbrıs'taki Meryem Ana Manastırı'nda bulunan 180 rahip ve Eğin'deki Ermeni ruhban da cizye ödemekteydiler. ${ }^{98}$ Dolayısıyla nispeten çok borç aldığını gördüğümüz Kenofon da muhtemelen 100 altını ödeyen ve "kâr ü kisbe kâdir" olan ruhban zümresindendi. Nitekim Kenofon'un sadece Mustafa Beşe'den değil kendi dindaşlarından da yüksek meblağlarda borç aldığ 1 görülmekteydi. Nefs-i Trabzon zimmîlerinden Hace Kakol v. Nikola, Anderye v. Efkasend ve Gorgor v. Bireşkove, Metropolit Kenofon'a 100.000 akçe borç vermişlerdi. Metropolit bu borcun 80.000 akçesini ödemiş ve bu da evail-i Cemaziyelahir 1030 (23 Nisan-2 Mayıs 1621) tarihinde sicile kaydedilmişti. ${ }^{99}$

Kenofon'un ölümünden sonra oğlu Efkasend mahkemeye gelerek, babası Kenofon'un muhallefatına, emval ve erzakına "vaz"-1 yed" eylememiş iken babasının ve dedesinin alacaklılarının kendisinden bu borçları istediklerini ifade etmişti. Bundan sonra babasının muhallefatına, evine ve çiftliğine "vaz'-1 yed" eylemediğini ve eylemeyeceğini de eklemişti. Alacaklıların mahkeme tarafından vekil tayin ettirip ve muhallefatı "izn-i şer" ile sattırıp alacaklarını buradan tahsil etmeleri gerektiğini bildirmişti. Ayrıca elinde bu istikamette fetva olduğunu, buna bakılıp kendisine hüccet verilmesini talep etmişti. Neticede evâsıt-1 Cemaziyelevvel 1038 (6-15 Ocak 1629) tarihinde kendisine talep ettiği hüccet verilmişti. ${ }^{100}$ Böylece Melnik (?) v. Yani ve Anderye v. Yani, Kostantin v. Komanid, Sohar v. Yani ve Efendol v. Bendazi adlı zimmîler, meclis-i şer'de Yason (?) v. Liyu adlı zimmî muvacehesinde ikrâr etmişler, bundan önce Trabzon metropoliti iken ölen Kenofon'un Ahmed Beşe'ye olan borcuna "kefil bi'l-mâl" olmuşlardı. Metropolitin oğlu Efkasend ve kızı Lomerse (?), babalarının muhallefatı borcuna kifayet etmediği için muhallefata "vaz"-1 yed" etmemişlerdi. Bunun üzerine adları geçen zimmîler kefaletleri hasebiyle metropolitin muhallefatının "izn-i şer'le" sattırılmasına ve Ahmed Beşe'ye olan borcunun ödenmesine mahkeme tarafindan vekil olmuşlardı. Böylece Kenofon'un Ganita Mahallesi'nde bulunan bir tarafı deniz kenarına, bir tarafı Hallaç Andon mülküne, bir tarafı kızının zeytinliğine bitişik ve bir tarafı umumi yola bakan kiremit örtülü fevkani ve tahtani evleri ve bahçesi, meyveli ve meyvesiz ağaçlarıyla birlikte, ayrıca yine söz konusu sınırlar içerisinde yıkılmaya yüz tutmuş harabe bir ev, kenef ve sekiz adet zeytin ağacı suk-1 sultanide açık artırmaya çıkarılmış ve 235 adet kâmil kuruşa Yason adlı zimmî üzerinde kalmıştı. ${ }^{101}$ Yine daha önce Yeniçeri Ahmed Beşe b. Abdullah, Melnik v. Yani, Efendol v. Bendazi, Anderye v. Yani ve Sohar adlı zimmîlerin kefaletiyle Metropolit Kenofon'a "karz-1 şer'î” 200.000 akçe vermişti. Adı geçen meblağın bir miktarını Kenofon'dan

\footnotetext{
${ }^{96}$ Daniel Goffman, İzmir ve Leventen Dünya (1550-1650), (çev. Ayşen Anadol-Neyyir Kalaycioğlu), Tarih Vakfi Yurt Yayınları, İstanbul 1995, s. 35; Kenanoğlu, Osmanlı Millet Sistemi, s. 389.

${ }^{97}$ T.Ş.S., 1828, 156/2.

${ }^{98}$ Kenanoğlu, Osmanlı Millet Sistemi, s. 387-388.

${ }^{99}$ T.S.S.S., 1821-4, 89/9.

100 T.S.S., 1825, 90/8.

${ }^{101}$ T.Ş.S., 1825, 102/6.
} 
almış; fakat rahip ölünce geriye kalan kısım zimmetinde kalmıştı. Dolayısıyla kefil olan zimmîlerden rahibin muhallefatından olup satılan Sabuğa/Coğa (?) adlı köyde bulunan çiftliği bahasından 300 kuruş, Ganita Mahallesi'ndeki evden 238 kuruş ve Melcan oğlu Mustafa Beşe'den "salyâne olunan akçeden" 100 kuruş, katır bahasından 50 kuruş, Baba Yur'dan 70 kuruş, Sohar'dan 60 kuruş ve metropolitten 60 kuruş ki toplamda 888 kuruşu almıştı. ${ }^{102}$ Kenofon'un bir başka alacaklısı da Urganciyan Mahallesi sakinlerinden Kostantin v. Komayzid (?) adlı zimmî idi. Kostantin yine aynı mahalle sakinlerinden Yordan adlı zimmîden davacı olmuştu. Bundan önce Trabzon metropoliti olan Kenofon adlı rahipte 40.000 akçe alacağ ${ }_{1}$ vardı. Adı geçen mahalledeki evinin yarısı kendisinin ve diğer yarısı Mustafa Beşe'nin mülkü idi. Zikrolunan evin diğer yarısını metropolitte olan alacağı mukabili Mustafa Beşe'den alması için Kenofon'u vekil eylemişti. Rahip de evin yarısını Kostantin için 14.000 akçeye satın almıştı. Fakat Yordan evi zapt etmişti. Mahkemenin nihayetinde evin Kostantin'e verilmesi kararlaştırılmıştı. ${ }^{103}$

Netice itibarıyla zikredilen kayıtlar Kenefon'un sahip olduğu mülkler ve sosyoekonomik muhiti hakkında kısmen bilgi sağlamakta idi. Ne yazık ki diğer metropolitlere dair bu istikamette bilgi edinmek mümkün olmamıştır. Sadece Orta Hisar sakinlerinden Fazlullah Bey b. Abdulbaki Paşa'nın Aya Filibo Mahallesi'ndeki 60 dip zeytin, 7 dip servi ağaçları ve 1 adet ceviz ağacı ile taş duvarlar ve başka meyveli-meyvesiz ağaçlardan müteşekkil ve çeşmenin yanında bulunan mülkünün yanında cinsi belli olmamakla birlikte metropolit Filotheos'un da mülkleri olduğuna dair bir kayıt vardır. ${ }^{104}$ Konumuzla doğrudan bağlantılı olmasa da Ermeni metropoliti Verasod da Meydan-1 Şarkî Mahallesi'nde bir tarafı Ermeni kilisesine, bir tarafı Kuyumcu Kayola mülküne, bir tarafı Kaçadir (?) oğlu mülküne ve bir tarafi da Meydan yoluna bitişik olan yıkık mülk menzil arsasını Ali Beşe b. Osman Beşe'ye 137 riyalî kuruşa satmıştı. ${ }^{105}$ Bir başka Ermeni metropoliti Evânis de, Ermeni taifesinden Bedros'un ölen babası Mirserkis'in hizmetkârı ile birlikte Lehistan'dan gönderdiği ve Bedros'un büyükannesi Sultanpaşa (?) elinde olan 770 kuruşluk bir sandığa el koymuştu. Bunun yanında Bedros'un babası Leh tarafinda öldükten sonra varıp 500 kuruşluk sahtiyanı da ele geçirmişti. ${ }^{106}$

\section{Sonuç}

İmparatorluk şehirlerinin (mahrûse) kozmopolit karakteri, aynı zamanda İmparatorluğun kozmopolis (nizâm-1 âlem) idealli bir siyasal mekanizma olduğunun en önemli göstergesi idi. Kozmopolit şehirlere hükmeden Osmanlılar, fütuhatçı bir dünyada, bu şehirlerin yenilerini fethedip idare edebilmede eski dünyanın bütün imparatorluk geleneklerini tevarüs etmeleri hasebiyle önemli bir birikime sahiplerdi. Bu birikimin hukukî zeminini ise fikıh teşkil etmekte ve bunun örfle buluştuğu nokta Osmanlı geleneğinde "istimalet" olarak ifadesini bulmaktaydı. Daha kuruluş yıllarından itibaren gayrimüslim unsurlarla bu hukuki zemin ve gelenek üzerinden ilişki kuran Osmanlılar, kısa süre içerisinde metropolitlik makamını kendi bünyesine dâhil etmeyi becerebilmiş ve bunu bazı araştırmacılara göre "ruhani iltizâm sistemi" çerçevesinde İmparatorluk teşkilatına en uygun şekle büründürmüş̧ü.

Pişkeş ödemeleri ile müşahhaslaşan bu teşkilatlanma, İmparatorluğun 17. yüzyılında ve Trabzon özelinde metropolitlerin görevde kalma sürelerinin nisbî uzunluğu ile belli bir istikrara işaret ediyorsa da, 17. yüzyıldaki "kriz"in metropolitliğe de kısmen yansıdığı görülmekteydi. Gerek metropolitlik beratı gerekse gönderilen hükümlerde metropolitlerin vazifeleri, bilhassa vergi toplamak noktasında yoğunlaşıyordu. İşte bu vergiler, İmparatorluğun merkezî bürokrasisi ile taşra bürokrasisi ve gayrimüslim reaya ile bunların ruhanî/mâlî liderleri arasındaki en mühim bağlantı noktası idi. Nitekim 17. yüzyıla gelindiğinde metropolitler bu vergileri toplarken ve

\footnotetext{
${ }^{102}$ T.Ş.S., 1826, 48/10. Evâhir-i Zilhicce 1038. (11-20 Ağustos 1629).

${ }^{103}$ T.Ş.S., 1825, 115/3. Evâsit-1 Cemâziyelevvel 1038 (6-15 Ocak 1629).

${ }^{104}$ T.S..S., 1840, 6/1. 1 Ramazan 1074 (28 Mart 1664).

105 T.Ş.S., 1831, 44/10. Evâhir-i Safer 1060 (23 Şubat-3 Mart 1650).

${ }^{106}$ T.Ş.S., 1836, 29/11. Evâil-i Zilkade 1067 (11-20 Ağustos 1657).
} 
diğer bazı vazifelerini icra ederken taşradaki ehl-i örf taifesi sıklıkla bunlara müdahale etmişler ve merkezî hükümet de bu müdahaleleri engellemek için hükümler göndermişti. Hatta kimi zaman metropolitlik gayrimüslim unsurlar arasında bir çekişme mevzuu olmuş ve ehl-i örf ile kurulan birtakım ittifaklar ile metropolitlik haksız yollardan elde edilmeye çalışılmıştı. Yine metropolitlik makamı ekseninde birtakım hizipleşmeler ortaya çıkmış ve reayanın da dâhil olduğu bu çekişmede taraflar birbirlerine galebe edebilmek için mahkemeyi manipüle etmeye çalışmışlardı. Bu gibi hususlar ile beraber düşünülebilecek bir başka durum da, metropolitlerin çoğu zaman reayadan haksız vergi talebinde bulunarak birtakım gayr-i hukukî icraatlara tevessül etmeleri idi. Hatta bu gayr-i hukukî zemin bir metropolitin bilhassa bir yeniçeriyi hedef olarak belirleyip dininin propagandasını yapmasına ve bir şekilde onu "oyuna" getirerek din değiştirtmeye çalışmasına kadar uzanmaktaydı.

\section{Ek}

\section{Trabzon Metropoliti Lavendros’un (Lavrentios) Muhallefatı}

Şer‘iye sicillerinde karşılaştığımız bir tereke, metropolitlerin nelere sahip olabildiklerini kısmen göstermesi açısından ele alınmaya değerdir. ${ }^{107}$ Kısmen denilmesi, terekenin metropolitin bütün mal varlığını yansıtmıyor olduğunu düşünmemizden kaynaklanmaktadır. Zira yukarıdaki Kenofon örneğinde görüldüğü üzere metropolitlerin ciddi sayllabilecek bir gayrimenkule de sahip olabildikleri anlaşılmaktadır. Fakat elimizde bulunan 1640/41-1659 y1lları arasında metropolitlik yapmış olan Lavendnos'un terekesinde hiçbir gayrimenkul yer almamaktadır. Bunun nedenini tayin etmek zordur. Bilindiği üzere ölenin akrabaları terekeden mal kaçırabilmekteydiler; ${ }^{108}$ küçük bir ihtimal olarak Lavendnos'un akrabaları da böyle bir yola tevessül etmiş olabilirler. Bu ihtimali küçük olarak değerlendirmemizin nedeni terekeden kaçırılan malların genelde yükte hafif pahada ağır mallar olmasındandır. Her ne olmuş olursa olsun tereke Lavendnos'un bütün mal varlığını yansıtmıyor gibi durmaktadır.

\begin{tabular}{|l|l|l|l|}
\hline 1 adet kırmızı çintiyan & 50 akçe & 1 adet metropolit tac1 & 1350 akçe \\
\hline 2 adet siyah bogasi kapamas & 300 akçe & $\begin{array}{l}2 \text { çift keşişlerin boyunlarına giydikleri } \\
\text { momor (?) tabir ettikleri nesne }\end{array}$ & 1620 akçe \\
\hline 1 adet köhne mor kalpağ1 & 60 akçe & 2 adet keşiş kolçağ1 & 300 akçe \\
\hline 1 adet mükellel (süslü) diz çakşırı & 60 akçe & keşişlerin başına giydiği 1 adet sarık & 20 akçe \\
\hline 1 çift mor çuka diz çakşırı & 340 akçe & 1 adet keşiş boğazlığ 1 & 100 akçe \\
\hline 1 adet Engürî kuşak & 20 akçe & 2 adet sagîr (?) keşiş kaftanı & 1800 akçe \\
\hline 1 adet Urum dülbendi & 20 akçe & 3 adet keşiş boğazlığ ve omuzluğu & 90 akçe \\
\hline 1 adet kemhadan kaftan & 720 akçe & 2 adet gümüşü kuşak & 1530 akçe \\
\hline 1 adet atlas kaftan & 540 akçe & 7 zira kemhadan keşiş boğazlığ1 & 120 akçe \\
\hline 1 adet siyah ferace & 2000 akçe & 2 adet kemhadan ... & 150 akçe \\
\hline 2 adet aba siyah dimi & 18 akçe & 1 adet sedefkâri metropolit asası & 900 akçe \\
\hline 3 adet puşi & 90 akçe & 1 adet sim haç şamdan & 2.250 akçe \\
\hline 8 adet keten gömlek & 800 akçe & sim haç & 1000 akçe \\
\hline 1 adet don-gömlek & 140 akçe & 1 adet Şamihi (?) teşbih & 40 akçe \\
\hline 1 adet köhne tomak & 30 akçe & 3 çift aynalı (?) tahta suret & 200 akçe \\
\hline
\end{tabular}

107 T.Ş.S., 1838, 60/4. Trabzon'da giyilen kiyafetlere dair bir araştırma için bkz. Eyyup Şimşek, “On Sekizinci Yüzyılın Başında Trabzon'da Giyim-Kuşam (1700-1725)”, MAVİ ATLAS GŞÜ Edebiyat Fakültesi Dergisi, S. 1, (2013), s. 51-66. 8 Mayıs 1821'de bütün mal varlığı sayılarak deftere geçirilmiş olan Patrik Kirilos'un “çeşitli cins ve değerde kürk, entari, peşkir, kumaş gömlek, şal gibi giyim eşyası, çekmece, çatal, kaşık, tabak, tepsi, çay ibriği, şeker hokkası gibi ev eşyası, tespih, haç, İncil, Kur'an, seccade gibi dinî eşyalar, yine çeşitli enfiye kutuları, altın saat gibi eşyaları olduğu anlaşılmaktadır." Bunun yanında sandığında 19.670,5 kuruş ve üzerinde de 1.425 kuruş bulunmuştur. Terekesi toplamda 41.835 kuruş 35 paradır. Ayrıca 39.750 kuruş tutarında borcu bulunmaktadır. Hamiyet Sezer Feyzioğlu, "Rum İsyanı Sırasında Edirne'de Öldürülen Eski Patrik'in Terkesine Dair Bilgiler”, XVI. Türk Tarih Kongresi (20-24 Eylül 2010, Ankara) Kongreye Sunulan Bildiriler, 4. Cilt 1. Kısım, Türk Tarih Kurumu Yayınları, Ankara 2015, s. 487.

${ }^{108}$ Feridun Emecen, “Ayan ve Muhallefatı: Karaosmanoğlu Hacı Mustafa Ağa”, Tarihin İçinde Manisa, Manisa Belediyesi Kültür Yayınlar, Manisa 2006, s. 203-210. Yavuz Cezar, "Bir Âyanın Muhallefatı: Havza ve Köprü Kazaları Âyanı Kör İsmail-Oğlu Hüseyin (Müsadere olayı ve terekenin incelenmesi), Belleten, C. XLI, S. 161, (Ankara 1977), s. 52-54. 


\begin{tabular}{|c|c|c|c|}
\hline 1 adet köhne tomak & 15 akçe & 16 adet İncil ve Zebur hikâye kitâbları & 720 akçe \\
\hline 1 çift hamam peştemali & 100 akçe & & \\
\hline 2 adet gök (?) peştamal & 60 akçe & & \\
\hline köhne siyah şal & 20 akçe & & \\
\hline $\begin{array}{l}50 \text { top beyaz ve işleme ve dokuma ve } \\
\text { tire makramaları }\end{array}$ & $\begin{array}{l}14.030 \\
\text { akçe }\end{array}$ & 1 adet beyaz köhne bohça & 20 akçe \\
\hline 17 adet kınnab & 25 akçe & alaca köhne bohça & 50 akçe \\
\hline 16 zira asdar & 60 akçe & 2 adet bohça & 190 akçe \\
\hline 1 adet başlık bogasi parçası & 30 akçe & 1 adet alaca bohça & 25 akçe \\
\hline 1 top beyaz bogasi & 100 akçe & 2 adet sepet sandik & 300 akçe \\
\hline 1 [top] mavi bogasi & 90 akçe & 1 çift köhne girar (k1l çuval) & 60 akçe \\
\hline 18 zira dimi & 18 akçe & & \\
\hline Londura çukası & 10 akçe & & \\
\hline köhne sof (?) & 60 akçe & & \\
\hline 10 zira beyaz bezlik & 120 akçe & & \\
\hline köhne sof & 450 akçe & & \\
\hline 50 dirhem biber & 15 akçe & mürekkeb eczası & 12 akçe \\
\hline 60 dirhem zağferan (safran) & 120 akçe & 1 adet Acem devat1 & 25 akçe \\
\hline 7 kile şeker & 200 akçe & 8 deste kâğıt & 80 akçe \\
\hline balık oltaları & 30 akçe & 6 adet sünger (?) & 20 akçe \\
\hline 1 adet siyah sirça mesina & 5 akçe & 2 adet köhne peşkir & 40 akçe \\
\hline 7 adet sim kaşık & 1000 akçe & 1 adet sedef sakal tarağ 1 & 120 akçe \\
\hline 3 deste kaşık & 30 akçe & 1 adet ayna taraklık & 100 akçe \\
\hline 1 adet küçük yaldızlı tas (?) & 60 akçe & 2 adet mikraz (makas) & 12 akçe \\
\hline 4 adet kalay tepsi & 100 akçe & 1 çift alaca kilim & 200 akçe \\
\hline 2 adet kalay sini & 90 akçe & 1 adet beyaz velense & 40 akçe \\
\hline 1 adet büyük sini & 360 akçe & 1 adet köhne kebe & 85 akçe \\
\hline 2 adet şamdan & 120 akçe & 1 adet kırmızı köhne velense & 215 akçe \\
\hline 2 adet bozulmuş (?) ayna feneri (?) & 170 akçe & 1 adet beyaz Yanboli (?) & 140 akçe \\
\hline 1 adet cam tepsi & 45 akçe & 1 adet mavi Yanboli (?) & 60 akçe \\
\hline \multirow[t]{2}{*}{2 adet fincan ve fincan kutusu } & 18 akçe & 2 adet yastık & 60 akçe \\
\hline & & 1 adet köhne kebe & 40 akçe \\
\hline 12 vukiyye sabun & 36 akçe & 10 dirhem gümüş çubuk & 100 akçe \\
\hline 1 adet güğüm & 200 akçe & 4 dirhem gümüş parçası & 80 akçe \\
\hline 5 adet küçük Macar nacakları & 100 akçe & 1 adet küçük terazi & 20 akçe \\
\hline nakit & 540 akçe & 2 veznesiyle vezne kutusu & 90 akçe \\
\hline \multicolumn{2}{|l|}{ Toplam } & \multicolumn{2}{|l|}{25.449 akçe } \\
\hline
\end{tabular}

\section{Kaynakça}

\section{Arşiv Belgeleri}

\section{Başbakanlık Osmanlı Arşivi}

Kamil Kepeci Piskopos Mukataası Kalemi Defterleri (KK.d), no: 2542.

Mühimme Defterleri (MD), no: 79, 80.

\section{Şer'iye Sicilleri}

Trabzon Şer 'iye Sicilleri (T.Ş.S.), no: 1821-4, 1822, 1824, 1825, 1826, 1827, 1828, 1831, 1832, 1834, 1836, 1838, 1840, 1841, 1842, 1861.

İstanbul Kadı Sicilleri İstanbul Mahkemesi 24 Numaralı Sicil (H. 1138-1151/M. 1726-1738), C. 21, (ed. Coşkun Yılmaz, haz. Fuat Receb vd.), İSAM Yayınları, İstanbul 2010.

İstanbul Kadı Sicilleri Eyüp Mahkemesi 90 Numaralı Sicil (H. 1090-1091/M. 1679-1680), C. 31, (ed. Coşkun Yılmaz, haz. Fuat Recep vd.), İSAM Yayınları, İstanbul 2010

\section{Telif Eserler}


Acun, Fatma, "Osmanlı İmparatorluğu'nda Gayrimüslim Din Adamlarına Verilen İmtiyazlar: 16. Yüzyılda Tur-1 Sina Manastırı", XIV. Türk Tarih Kongresi, 9-13 Eylül 2012, C. II, Kısım II, Türk Tarih Kurumu Yayınları, Ankara 2005, s. 1403-1411.

Adıyeke, Nuri, "Osmanlı Millet Sistemine Dair Tartışmalar ve Siyasal Bir Uzlaşma Modeli Olarak Osmanlı Millet Sistemi”, Yeni Türkiye, S. 60, (2014), s. 1-13.

Ahmet Refik, Hicrî On Birinci Asırda İstanbul Hayatı (1000-1100), Devlet Matbaası, İstanbul 1931.

Akgündüz, Ahmed, Osmanlı Kanunnâmeleri ve Hukukî Tahilleri: 1. Kitap Osmanlı Hukukuna Giriş ve Fatih Devri Kanunnâmeleri, Osmanlı Araştırmaları Vakfı Yayınları, İstanbul 2006.

Antov, Nikolay, "Kisve Bahası Arzuhalleri: Osmanlı Döneminde Balkanlarda İslamlaşma Sürecine Dair Bir Kaynak”, Kebikeç, S. 10, (2000), s. 89-105.

Araz, Yahya, Klasik Dönem Osmanl Toplumunda Müslim Gayrimüslim İlişkileri Bağlamında Lise Tarih Ders Kitaplarında 'Öteki’ Sorunu, Dokuz Eylül Üniversitesi, Eğitim Bilimleri Enstitüsü Basılmamış Doktora Tezi, İzmir 2008.

Aygün, Necmettin, “Akçaabat'ta Gayrimüslim Osmanlı Vatandaşlarının Kilise ve Mektep İnşaatları", Dünden Bugüne Akçaabat, Akçaabat Belediyesi Kültür Yayınları, İstanbul 2014, s. 121-150.

Barkey, Karen, Farklılıklar Imparatorluğu: Karşılaştırmalı Tarih Perspektifinden Osmanlılar, (çev. Ebru K1lıç), Versus Kitap, İstanbul 2011.

Bozkurt, Gülnihal, Gayrimüslim Osmanlı Vatandaşlarının Hukukî Durumu (1839-1914), Türk Tarih Kurumu, Ankara 1996.

Cezar, Yavuz, "Bir Âyanın Muhallefatı: Havza ve Köprü Kazaları Âyanı Kör İsmail-Oğlu Hüseyin (Müsadere olayı ve terekenin incelenmesi), Belleten, C. XLI, S. 161, (Ankara 1977), s. 41-78.

Çiçek, Kemal, “Osmanlılar ve Zimmler: Papa Pavlos'nun İslam'a Hakareti ya da Renklere İsyanı”, Kıbrıs'tan Kafkasya'ya Osmanl Dünyasinda Siyaset, Adalet ve Raiyyet, Derya Kitabevi, Trabzon 1998, s. 135-146.

Çiçek, Kemal, "Şer'iye Sicillerine Göre Trabzon’da Müslim-Gayrimüslim İlişkileri”, Trabzon Tarihi Sempozyumu Bildirileri 6-8 Kasım 1998, (haz. Kemal Çiçek vd.), Trabzon Belediyesi Kültür Yayınları, Trabzon 2000, s. 235-243.

Eliot, Charles, Avrupa'daki Türkiye, C. 2, (çev. Adnan Sınar-Ş. Serdar Türet), Tercüman 1001 Temel Eser, ts.

Emecen, Feridun, "Ayan ve Muhallefatı: Karaosmanoğlu Hacı Mustafa Ağa”, Tarihin Iç̧inde Manisa, Manisa Belediyesi Kültür Yayınlar, Manisa 2006, s. 203-210.

Emecen, Feridun M., Osmanlı Klasik Çağında Hanedan Devlet ve Toplum, Timaş Yayınları, İstanbul 2011.

Ercan, Yavuz, "Türkiye'de XV. ve XVI. Yüzyıllarda Gayrimüslimlerin Hukuki, İctimai ve İktisadi Durumu”, Belleten, C. XLVIII, S. 188, (1983) , s. 1119-1150.

Ercan, Yavuz, Osmanlı Yönetiminde Gayrimüslimler, Turhan Kitabevi, Ankara 2001.

Gencer, Bedri, "Osmanlı'da Meşruiyet Tabakalaşmasının Oluşumu”, İstanbul Üniversitesi Siyasal Bilgiler Fakültesi Dergisi, S. 30, (2004), s. 65-100. 
Gencer, Bedri, "Hikmet Çağından İdeoloji Çağına Müsâlemeden Muhâsamaya”, Birlikte Yaşamak, (ed. Ahmet Kavlak-Muhammet Enes Kala), Hece Yayınları, Ankara 2015, s. 97-113.

Goffman, Daniel, İzmir ve Leventen Dünya (1550-1650), (çev. Ayşen Anadol-Neyyir Kalaycıoğlu), Tarih Vakfı Yurt Yayınları, İstanbul 1995.

Imber, Colin, "Hükümet, İdare ve Hukuk”, Türkiye Tarihi 1453-1603, (ed. Suraiya FaroqhiKate Fleet, çev. Bülent Üçpunar), Kitap Yayınevi, İstanbul 2016, s. 261-302.

İnalc1k, Halil, “Ottoman Archival Materials on Millets”, Christians and Jews in The Ottoman Empire, The Functioning of A Plural Society, (ed. B. Braude-B. Lewis), C. I, New York 1982, s. 437-449.

İnalcık, Halil, "The Status of the Greek Orthodox Patriarch under the Ottomans", Turcica, vol. 21-23, (1991), s. 407-435.

İnalcık, Halil, Osmanlı İmparatorluğu Klâsik Çăg (1300-1600), (çev. Ruşen Sezer), Yapı Kredi Yayınlar1, İstanbul 2004.

İnalcık, Halil, “Osmanlı Fetih Yöntemleri”, Söğüt'ten İstanbul'a: Osmanlı Devleti’nin Kuruluşu Üzerine Tartışmalar, (der. Oktay Özel-Mehmet Öz), İmge Yayınları, Ankara 2005, s. 443-472.

İnalcık, Halil, Devlet-i 'Aliyye: Osmanlı Imparatorluğu Üzerine Araştırmalar-IV, Türkiye İş Bankası Kültür Yayınları, İstanbul 2016.

İnan, Kenan, "Trabzon Kadı Sicillerinde Girit Seferi Hakkında Kayıtlar (1648-1669)", Uluslararası Osmanlı Tarihi Sempozyumu Bildirileri (8-10 Nisan 1999), (haz. Turan Gökçe), Türk Ocakları İzmir Şubesi Yayınları, İzmir 2000, s. 295-309.

İnan, Kenan, “Trabzon'un Fethi”, Öncesi ve Sonrastyla Trabzon'un Fethi, (haz. İsmail Hacıfettahoğlu), Trabzon Belediyesi Kültür Yayınları, Ankara 2001, s. 106-117.

İlgürel, Mücteba, “İstimâlet”, D.İ.A., C. 23, İstanbul 2001, s. 362-363.

Kafadar, Cemal, Kendine Ait Bir Roma: Diyar-ı Rum'da Kültürel Coğrafya ve Kimlik Üzerine, Metis Yayınları, İstanbul 2017.

Karaca, Filiz, "Pişkeş", DİA, C. 34, İstanbul 2007, s. 294-296.

Kenanoğlu, M. Macit, “Osmanlı Devleti’nin Gayrimüslim Teb'anın İdaresinde Kullandığı Bir Yöntem Olarak 'Ruhanî İltizam’ Sistemi”, Dîvân İlmî Araştırmalar, S. 14, (2003/1), s. 67-84.

Kenanoğlu, M. Macit, “İslam-Osmanlı Hukukunda Zimmîler”, Türkiye Araştırmaları Literatür Dergisi, C. 3, S. 5, (2005), s. 553-574.

Kenanoğlu, M. Macit, Osmanlı Millet Sistemi: Mit ve Gerçek, Klasik Yayınları, İstanbul 2007.

Kenanoğlu, M. Macit, “Zimmî (Osmanlılar'da)”, D.İ.A., C. 44, İstanbul 2013, s. 438-440.

Masters, Bruce, "Değişen Bir Dünyada Hıristiyanlar", Türkiye Tarihi 1603-1839, (ed. Suraiya Faroqhi-çev. Fethi Aytuna), Kitap Yayınevi, İstanbul 2011, s. 329-337.

Ortaylı, İlber, “Osmanlı İmparatorluğu'nda Millet”, Tanzimat’tan Cumhuriyet'e Türkiye Ansiklopedisi, C. 4, İletişim Yayınları, İstanbul 1985, s. 996-1001.

Ortaylı, İlber, Osmanlı Barışı, Ufuk Kitap Yayınları, İstanbul 2004.

Örsten Esirgen, Seda, "İslam-Osmanlı Ceza Hukukunda Zimmîler", Marmara Üniversitesi Hukuk Fakültesi Hukuk Araştırmaları Dergisi-Mehmed Akif Aydın'a Armağan, C. 21, S. 2, (2015), s. 187-213. 
Özel, Ahmet, Dârulİslâm Dârulharb: İslâm Hukukunda Ülke Kavramı, İz Yayınc1lık, İstanbul 2014.

Özgeren, Aydın, Millı̂ Mücâdele Döneminde Trabzon Rum Metropolitliği’nin Faaliyetleri, Ankara Üniversitesi, Basılmamış Yüksek Lisans Tezi, Ankara 2006.

Sezer Feyzioğlu, Hamiyet, "Rum İsyanı Sırasında Edirne'de Öldürülen Eski Patrik'in Terkesine Dair Bilgiler”, XVI. Türk Tarih Kongresi (20-24 Eylül 2010, Ankara) Kongreye Sunulan Bildiriler, 4. Cilt 1. Kısım, Türk Tarih Kurumu Yayınları, Ankara 2015, s. 485-495.

Şimşek, Eyyub, “On Sekizinci Yüzyılın Başında Trabzon'da Giyim-Kuşam (1700-1725)”, MAVİ ATLAS GŞÜ Edebiyat Fakültesi Dergisi, S. 1, (2013), s. 51-66.

Tosun, Miraç, XVIII. Yüzyıl Trabzon'unda Cemaatler Arası İlişkiler, İstanbul Üniversitesi Sosyal Bilimler Enstitüsü, Basılmamış Doktora Tezi, İstanbul 2013. 